\title{
Obesity and Socioeconomic Status Among Peruvian Women: Evidence of Panel Data Analysis
}

\author{
Tahereh Alavi Hojjat \\ DeSales University \\ Juan Daniel Morocho Ruiz \\ National Institute for the Defense of Competition and the \\ Protection of Intellectual Property
}

\begin{abstract}
The rise in global obesity and overweight population rates has reached a pandemic level. This dramatic rise in rates is more pronounced in developing countries, as compared to more industrialized societies. In Peru, obesity rates are escalating, the information available shows that during the years 2008 and 2017 the rate of obesity among Peruvian women increased from 14.60 to 22.91 percent, despite the progress made in reducing poverty and income inequality during the reference period. In this paper, Panel-data analysis from 2008-2017, 24 regions, and a sample size of 240 data points is used. We find that there is a cointegration among obesity, poverty, and income inequality, which ensures a long-run relationship among the variables.
\end{abstract}

Keywords: Obesity, Medical Costs, Economics, Cointegration, Inequality Gap, Poverty, Food Prices, Panel Data Analysis

\section{INTRODUCTION}

While some countries are suffering from food scarcity, at the same time, a significant number of countries are dealing with the opposite problem: excess weight and obesity. For the first time, there are more overweight people in the world than people suffering from malnutrition. In 2016, more than 1.9 billion adults, 18 years and older were overweight. Of these, over 650 million were obese (The World Health Organization, 2018). Overweight and obesity refer to an excess of body fat and it relates to increased weight for height. The most common method of measure of obesity is the Body Mass Index (BMI). In adults, a BMI of 25 to 29 means overweight, a BMI of 30 or higher means that person is obese.

Obesity has become the worst nutritional threat in Latin America, adding to the overweight population at a rate of 3.6 million annually (United Nation Report, 2018). According to the United Nation Report (2018), hunger affects over 39 million Latin Americans, or just over 6 percent of the population. Between 2016 and 2017, the total increased by 400,000 people, twice as many as it did in the previous year (ibid).

Latin America is also a region with the highest rates of inequality in the world. This part of the American continent is home to scenarios of growth with poor income distribution, stagnation, or poverty. 
A meta-analysis conducted by the World Health Organization (WHO) showed that $58.2 \%$ of adults over 18 years of age in Peru are overweight or obese; that is well over half of the population (cited in Fallon, 2015).

According to the National Institute of Statistics and Informatics and the World Bank, Peru is an upper-middle income country with an estimated 2017 population of 32 million people. Peru's per-capita Gross National Income (GNI) during the same year was \$5,960 (The World Bank, Peru, 2019) and 6.9 million, or 44 percent, live in poverty with about $21.7 \%$ of the population living below the poverty line. On the other hand, the inequality of income, as measured by the Gini Coefficient, decreased from 0.48 to 0.43, from 2008 to 2017 (Figure 1). This indicator shows that Peru is a country with high inequality as the Gini coefficient is above 0.30, a threshold at which nations are generally considered to have a more equitable distribution of income.

\section{FIGURE 1 \\ GINI COEFFICIENT, PERÚ: 2008-2017}

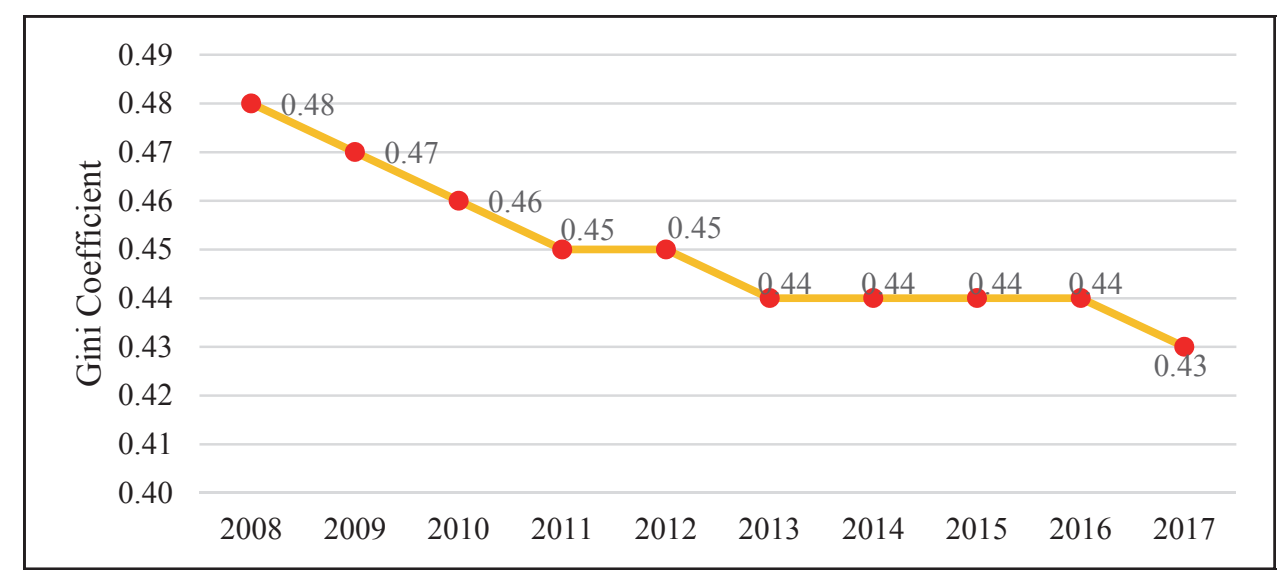

Source: National Institute of Statistics and Informatics (INEI). Evolution of Monetary Poverty 2007-2017.

Over the past several decades, obesity has become a significant global epidemic. Numerous factors contribute to obesity, among which are consumption of high-fat, carbohydrate-dense foods and physical inactivity, which could affect obesity rates and differences in rates by country, in both rich and poor subgroups (Monteiro, et al. 2004).

In addition, the relationship between obesity and socioeconomic status (SES) in both industrial and developing countries have been extensively investigated. Populations of lower socioeconomic status in developed countries experience more incidences of obesity than those of higher economic status. However, there is still debate as to whether the same phenomenon occurs in developing countries (Dinsa, et al. 2012). The literature indicates that people with low socioeconomic levels in developed countries have higher rates of obesity, while in middle- and low-income countries, the opposite phenomenon occurs (Poskitt, 2014). Hojjat and Hojjat (2017) confirmed that a long-term relationship exists among obesity, income inequality, and poverty in the U.S., finding that the greater the income inequality and poverty, the higher the obesity rate. Salmasi \& Celidoni (2017) studied the effect of income and wealth-based poverty on the probability of being obese for the elderly in Europe. Their study shows that poverty significantly increases the likelihood of being obese for both men and women.

Unlike industrial countries, the trend in developing countries may differ. For example, a study performed by Hou, etal. (2008) in urban China found that higher household income was associated with higher obesity risk, whereas women with higher education had a reduced risk of obesity. However, both higher education and income have been associated with increased obesity rates in Bangladesh (Khan \& Kraemer, 2009). Among a sample of Indian subjects, Subramanian \& Smith (2006) found higher obesity rates among wealthy women in both rural and urban settings, which increased with degree of 
urbanization. Monteiro, et al., (2001) found out that there are within-country variations in the association between socioeconomic status (SES) and obesity. In Brazil obesity were greater in individuals with higher incomes in disadvantaged region in Brazil (Subramanian \& Smith, 2006). Further, Fernald (2007) performed a study in Mexico examining the relationship between income and obesity in poor, rural regions of Mexico and found that higher SES was associated with higher odds of obesity.

Low- and middle-income countries, such as those in Latin America, are undergoing a rapid epidemiological and nutritional transition. Some factors responsible for this shift are urbanization, changes in dietary patterns and reduction of physical activity, resulting in increased rates of obesity (Prentice, 2006, Popkin, 2001, Uaury, et al. 2001).

When people shift from an agricultural region to an urban lifestyle, there are dietary effects. In Peru, an agrarian lifestyle is highly active, where caloric input is offset by hard manual labor. After moving to an urban setting, a less active lifestyle combined with the same caloric intake as before leads to weight gains, intensified by additional food choices such as processed foods and fast foods that are readily accessible, low-cost, and enticing (Fallon, 2015). As a result, obesity rates in Peru have been escalating and vary according to the area of residence and socioeconomic position, particularly in women where obesity has been linked to higher wealth, lack of education, and urban settings (Poterico, et al. 2012).

According to the 2015 World Health Organization, (WHO), Peru had the highest fertility rate in the Latin American region in 2012. Huayanay-Espinoza, et al. (2017) found a positive and strong association between parity and obesity, mainly in young and rural women. This finding shows that parity, especially in young, rural women, is an independent key factor in increasing rates of obesity. The rural population is also characterized by low levels of access to prenatal care among women in urban areas and older women, evidenced by the lack of linkage between training programs of health professionals and primary care (Jimenez, et al. 2015). Moreover, training programs were outdated because of current epidemiological changes (ibid). Lucas, et al. (2014) found that pregnant women, especially those who are at risk of obesity, gestational diabetes, or malnutrition receive inadequate education about nutrition due to time constraints, lack of resources, and improperly trained health care providers. Women in developing countries, especially in the most at-risk regions, experience high prevalence of malnutrition. However, in Peru where epidemiological shifts are taking place, obesity has almost tripled in women between the ages of 20 and 50, particularly in rural regions (Loret de Mola, et al. 2014).

Lowering obesity is quite critical for developing countries as it can contribute to higher economic growth and lower government costs. Research conducted by Aghion, et al. 2010 utilized a cross-country regression analysis over the period 1960-2000 to investigate the relationship between health and economic growth as measured by GDP per capita in light of modern endogenous growth theory. The researchers found that a higher initial level of life expectancy, and a higher rate of improvement in life expectancy, have a significantly positive impact on per capita GDP growth. The main reasons for these findings are that individuals with higher life expectancy are likely to save more, and savings, in turn, contribute back into capital accumulation, and therefore into GDP growth. In addition, individuals with higher life expectancy are likely to invest more or to have their parents invest more, in education, which in turn should be growth-enhancing. Finally, and more directly, healthier individuals are typically more productive, better at creating and adapting to new technologies and generally more able to cope with the rapid changes characteristic of a high growth environment (Howitt, 2005).

Obesity became a global concern, not just limited to developing countries, as most of the world has grown fatter since the 1970s. According to the most recent figures from the UK National Archives (2018) 58 percent of women and 68 percent of men are overweight or obese. As the median person becomes fatter, it becomes socially acceptable to be fat (Jenkins, 2013). For obese children, 41 percent of mothers said their child was about the right weight or too light, with 59 percent describing the child is too heavy (Child Health, Health Survey of England, 2016).

Causes and consequences of obesity are beyond the scope of this paper, as the heterogeneous population at the individual level can be very complex. However, it is crucial to understand better the potential risk factors associated with high rates of obesity. Thus, the present study aimed to assess the 
association between poverty, income inequality, and obesity to help lawmakers design policies with the understanding of the contributing risk actors.

Therefore, this study includes an analysis of the issue from an economic point of view; considering the major factors contributing to obesity in general. The first part of this paper provides a brief introduction to the issue. Section two is a review of literature, and section three is a discussion of the relationship between poverty, income inequality, and obesity. Section four describes the model and methodology used in the present study. Section five reveals the results and discussion of the findings. An overview of food policy recommendations and interventions to fight obesity are presented in section six, and finally, section seven concludes the paper.

\section{Obesity}

The terms "overweight" and "obese" are used to express weight ranges that are greater than what is considered healthy for a given height. In the case of adults, weight and height are used to calculate "Body Mass Index" (BMI) to define what qualifies as overweight and obese. Standardized cutoff points for overweight and obese ranges: Normal weight is a BMI between 18.5 and 24.9; overweight is a BMI between 25.0 and 29.9; obese is a BMI of 30.0 or higher. For more details, see Table 1 on weight ranges. To calculate BMI using the metric system, weight in kilograms is divided by height in meter squared. Using the U.S. traditional system of weights and measures, BMI is calculated by dividing weight in pounds by height in inches squared, then multiplying by a conversion factor of 703 . Therefore, if a person is 5 feet and 6 inches tall and weighs 150 pounds, the BMI is 24.2. Calculation: [150 $\div(66) 2] \times 703=$ 24.2

TABLE 1 WEIGHT RANGE

\begin{tabular}{|l|l|l|l|}
\hline Height & Weight Range & BMI & Considered \\
\hline $\mathbf{5}^{\prime} \mathbf{9} "$ & $124 \mathrm{lbs}$. or less & Below 18.5 & Underweight \\
\hline & $125 \mathrm{lbs}$. to $168 \mathrm{lbs}$. & 18.5 to 24.9 & Healthy weight \\
\hline & $169 \mathrm{lbs}$. to $202 \mathrm{lbs}$. & 25.0 to 29.9 & Overweight \\
\hline & $203 \mathrm{lbs}$. or more & 30 or higher & Obese \\
\hline
\end{tabular}

Source: National Center for Health Statistics, 2011

In Peru, total spending is approximately 893 million dollars per year on weight-related diseases (Perú 21, 2017). Such conditions, including Type II diabetes, heart disease, hypertension, high cholesterol, gallbladder disease, and osteoarthritis, are merely on the top of the list of weight-related conditions. For example, $17.6 \%$ percent of obese adults have arterial hypertension (INEI, 2017), which is the leading cause of death in adults (Andina, 2012). Authorities view obesity as one of the most serious public health problems of the 21 st century (Barness, et al. 2007).

Peru is at a relatively early stage of nutrition transition, with obesity rates for Peruvian woman increasing from 9 percent in 1991 to 11 percent in 2005 (Mispireta, et al. 2007). However, during the period spanning 2008 to 2017, this rate of obesity has continued to increase markedly. In 2008, the obesity rate in women was 15 percent, which increased by 4 percent by 2011 . At the end of 2017 , the obesity rate had increased to 23 percent, which is equivalent to a 53 percent increase since 2008 . The prevalence of chronic obesity-related, non-communicable diseases, based on self-report surveys considering hypertension, diabetes, asthma, and other conditions together, increased from 20.5 percent in 2005 to 25.4 percent in 2009 (INEI, 2008). In 2012, obesity caused 22.77 percent of deaths due to cardiovascular diseases (La República, 2012), affecting more than 28 percent of Peruvians in 2014 (El Comercio, 2014).

At present, obesity is not only problematic from a clinical point of view; it is also a social issue of considerable importance. In addition to physical ailments, obesity has been empirically related to lower satisfaction with work, family relations, partner relationships, social activities, and even depression 
(Stutzer, 2007). Obesity increases the likelihood of various diseases, particularly coronary heart disease, Type 2 diabetes, certain cancers (endometrial, breast, and colon), hypertension (high blood pressure), dyslipidemia (high total cholesterol or high levels of triglycerides), stroke, liver and gallbladder disease, obstructive sleep apnea and other respiratory problems, osteoarthritis (degeneration of cartilage and its underlying bone within a joint), and gynecological problems (abnormal menses, infertility) (CDC.gov ). At all ages, obesity is associated with social isolation, depression, and other major mental health problems.

\section{LITERATURE REVIEW}

There has been an increase in the prevalence of obesity amongst both genders of all ages and ethnic and racial backgrounds. There are also numerous factors contributing to obesity, as presented in Figure 2. Energy-dense foods and energy-dense diets are blamed for the global obesity epidemic (French, Story, \& Jeffery, 2001). The energy density of food is defined as the energy per unit weight or volume (kcal/100g or mega-joules per kilogram). The frequency of consuming restaurant food was positively associated with increased body fatness in adults. Several studies investigated the reason for obesity including proportion of household food income spent on food prepared away from home (McCrory, et.al., 1999), snacks, sweets, and desserts (Zizza, et al. 2001), sweetened soft drinks (Bray, et al. 2004) and large portions sizes (Rolls, et al. 2002), which have all been linked to greater obesity risk.

FIGURE 2

\section{FACTORS AFFECTING OBESITY}

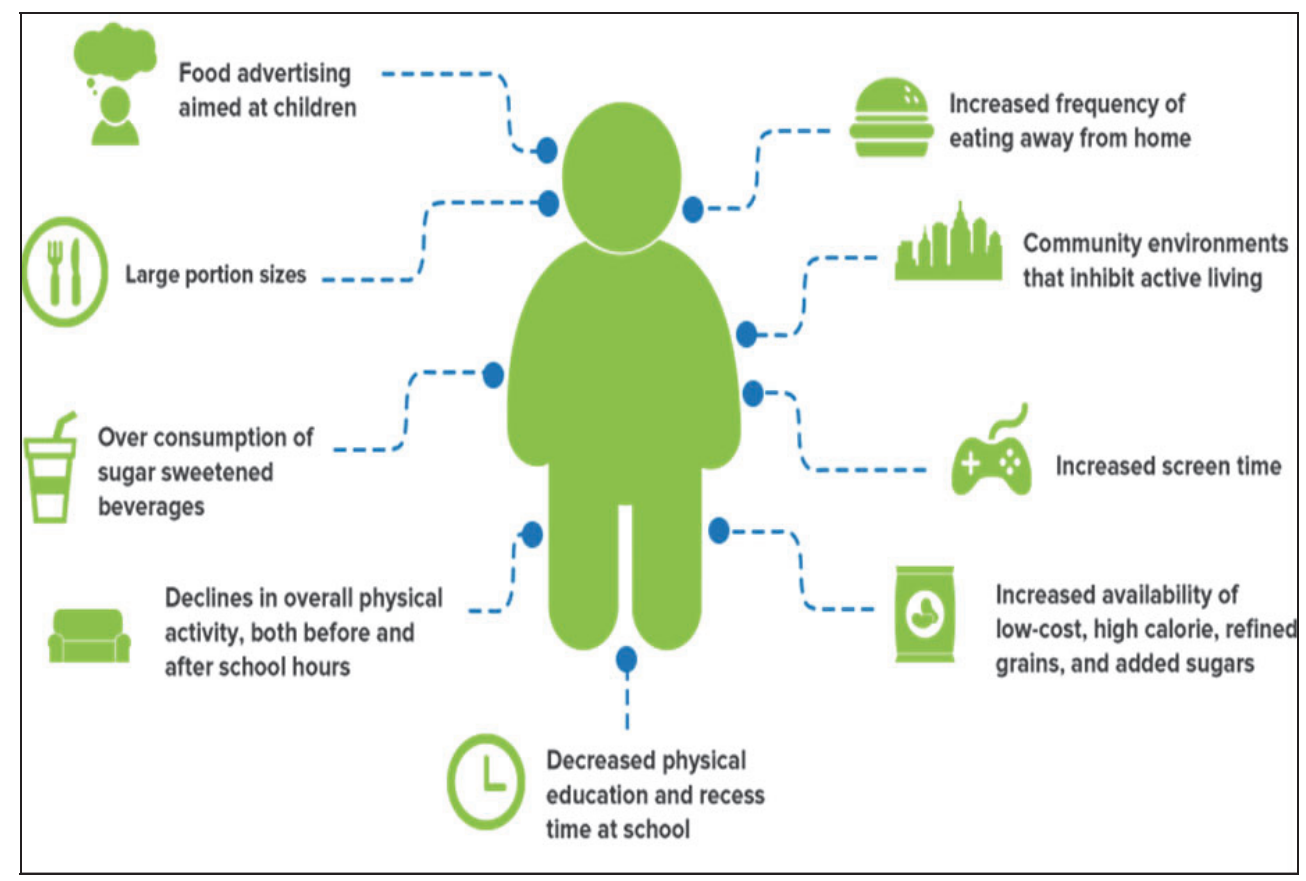

Source: Childhood obesity causes. (Childhood obesity 180.org.)

Several authors have offered explanations for the increase in adolescent obesity in Latin America. Martorell and co-authors (1998) have noted that the traditional diet of the region has undergone extensive modification such that it now resembles the high-fat, high-calorie diets consumed in industrialized societies. These authors speculate that consumption of high-calorie diets and a more sedentary lifestyle have resulted in an increase in the incidence of obesity and obesity-related degenerative disorders in the region. Troiano \& Flegal (1998) have observed that the increases in obesity worldwide are due to social 
and environmental factors including changes in parental employment patterns, increased television viewing, concerns about neighborhood safety, and the increased availability of video games. Findings from the present study suggest that another contributing factor to the increase in adolescent obesity in Latin America is a deficit in obesity knowledge in this age group.

Food choices are also made on the basis of taste, cost, convenience, and, to a lesser extent, health and variety (Glanz, et al. 1998). Variety relates to the innate drive to secure a varied diet, whereas health refers to concerns with nutrition, chronic disease, and body weight. The authors used a national sample of 2,967 adults. Response rates were 71 percent to the first survey and 77 percent to the second survey (which was sent to people who completed the first survey). Univariate analyses were used to describe importance ratings. Respondents reported that taste is the most important influence on their food choices, followed by cost. Their results suggest that nutritional concerns are of less relevance to most people than taste and cost. One implication is that nutrition education programs should attempt to design to promote nutritious diets as being tasty and inexpensive.

The basic idea related to the obesity infrastructure is that "the root of the [obesity] problem lies in the powerful social and cultural forces that promote an energy-rich diet and a sedentary lifestyle" (Brownell and Horgen, 2004). This environment has intensified over the past thirty years by opening more fast food restaurants and more advertising. The authors explore the economics of food and make it clear that the profit motive of the food industry is not consistent with the current nutritional needs of the nation. Health economists have demonstrated that the prevalence of obesity is directly proportional to food prices and access to restaurants (Chou, et al. 2004). They estimated the effects of fast-food restaurants advertising on children and adolescent being overweight. Their results indicate that a ban on these advertisements would reduce the number of overweight children ages of 3-11 in a fixed population by 18 percent and would reduce the number of overweight adolescents' ages of 12-18 by 14 percent (Chou, et al. 2008). Another study reveals causes range from a lack of education about food, limited cooking skills, and limited money to buy healthier food to longer working hours and marketing campaigns for junk food aimed at kids (Winterman, 2012).

Although the dramatic rise in obesity can only be explained by environmental factors, there has been little emphasis on the obese persons' economic environment. In particular, there has been little research on diet quality and economics of food choice. The broader problem may lie with poverty, growing disparities in incomes and wealth, declining value of the minimum wage, food imports, tariffs, and trade. Rising obesity rates reflect an increasingly unequal distribution of income and wealth. It is by now widely accepted that income poverty is a risk factor for premature mortality and increased morbidity (Subramanian \& Kawachi, 2004). There is in fact intriguing evidence that a person's socioeconomic position can affect health. Braveman (2014) insists that illness is caused by the power imbalance in the capitalist society. He emphasizes on the concepts of health disparities and health equity, and explains the rationale based on principles from the fields of ethics and human rights. We must counteract the free market with social programs.

According to Fineberg, former dean of the Harvard School of Public Health, "a school of public health is like a school of justice." Income inequality affects health by undermining civil society. Lack of social cohesion leads to lower participation in political activity (such as voting, serving in local government, volunteering for a political campaign). And lower participation, in turn, reduces government spending on public goods, such as education, and social safety nets (Satel \& Marmor, 2001). It is not just income dispersion itself that matters for health but the proportion of the population that suffers true poverty-related problems, such as under-nourishment, lack of access to timely medical care, and lack of access to healthy food and so on.

Choice of certain products and eating habits are closely related to preferences, lifestyle, culture, ethnicity, and income level. Since World War II, food tradition and culture of the industrialized countries have suffered a sudden and profound change: of course, economic development has led to greater availability and variety of food, but such availability resulted into greater obesity and diseases associated with it (Neel, 1962). In developing countries the food culture is changing, they tend to adopt eating habits similar to those of the western world, and they are particularly influenced by the industrialized American 
diet and availability of information and access to packaged food. In 1989, Sobel \& Stunkard (1989) published a seminal review of literature on the relation between socioeconomic status (SES) and obesity, they covered the 1960s through the mid-1980s and found 144 published studies on the SES-obesity relation in men, women, and children in developed and developing worlds. They found a consistently inverse association for women in developed societies with a higher likelihood of obesity among women in lower socioeconomic status. In developing societies, a strong direct relation was observed for women, men, and children, with a higher likelihood of obesity among persons in higher socioeconomic strata.

\section{POVERTY, INEQUALITY AND OBESITY}

According to the Office of Management and Budget, Annual Report (2017), poverty status or percentage of poverty level is based on family income, family size, and the number of children in the family, and for families with two or fewer adults, on the age of the adults in the family. The poverty level is based on a set of income thresholds that vary by family size and composition. Families or individuals with income below their appropriate thresholds are classified as below the poverty level. In Peru, the official poverty definition supported by the National Institute of Statistics and Informatics (INEI, 2000) uses the poverty line method is used for consumption, the value of all the goods and services consumed by the household is incorporated, regardless of the form of acquisition or attainment. The use of consumer spending has the advantage that is the best indicator to measure well-being because it refers to what a household consumes and not what it can potentially consume when measured by income. Another favorable aspect is that consumption is one more variable stable income, which allows better measurement of the poverty level trend.

In the estimates of consumption expenditure, all sources of expenditure are considered, monetary expenditure, as well as the various forms of acquisition of goods and services that do not imply a monetary payment of part. This last group includes self-consumption and self-supply, as well as in-kind payments that come from households' economic activities and also the elements of expenditure received by transfers from other households or by part of public and private organizations. Likewise, within the components of expenditure, expenses in health and public education are excluded, due to the lack of adequate prices to value said services consumed by households. Finally, the imputation for the consumption of river water or ditch is also excluded, because the degree of transformation of said goods is almost nil and there is no commercial value that allows an adequate valuation (INEI, 2018).

Peru has historically been one of the poorest and most unequal countries in Latin America. Sustained economic growth has reduced poverty by over half and extreme poverty by three fourths in the last ten years. However, poverty is still widespread among indigenous communities of the Andean highlands and Amazon jungle (Peru Reports, 2018). Peru's middle class is slightly smaller today than it was in 2011 according to a study by Lima's Chamber of Commerce. The seven Peruvian regions, which registered smaller middle classes include Huancavelica, Pasco, Amazonas, Piura, Ucayali, Cajamarca and Madre de Dios. On the other hand, four regions which saw slight increases in the size of their middle class included Ayacucho, Tumbes, San Martin, and Junin. According to the Peru Report 2015, of the 9.1 million Peruvians who belong to the middle class according to IEDEP's definition, over half live in Lima and Callao, and 20 percent live in Arequipa, La Libertad, Piura, and Cusco. Obesity is an increasing public health concern in several developing countries, including Peru. An analysis of Demographic and Health Survey (DHS) 1996 showed a 9.4 percent prevalence of obesity in Peruvian women. Data from the DHS 2008 showed a 14.3 percent prevalence of obesity, which is an increase of 52 percent in obesity rates in Peruvian women (Poterico, et al. 2012).

McArthur, et al. (2001) examined the effects of socioeconomic status (SES) on the obesity knowledge of adolescents in six Latin American cities. They found out that the weakest knowledge areas among youth from the higher SES groups were food preparation methods and the relationship between obesity and health while those for adolescents from the lower SES groups were the fat and calorie content of foods and beverages and the relationship between obesity and health. Classroom instruction about obesity was generally more available to students from the higher SES groups. The majority of adolescents from 
both SES groups were interested in learning more about weight loss methods, energy expenditure, and the fat and calorie content of foods and beverages. The topic of least interest was the relationship between obesity and health.

As the Economist magazine notes in its survey of obesity, "the rich and well-educated have mostly managed to stay slim." The relationship between obesity and poverty has become more obvious and complex: being poor in one of the poorest countries may be associated with poor nutrition, while being poor in a developed country could mean a higher risk of obesity. This concept is confirmed by Sobal and Stunkard (1989): in developed countries, there is an inverse relationship between obesity and socioeconomic status, the higher social classes can compensate for a sedentary lifestyle, with more information and sport opportunities, plus they can afford better quality food, organic and less processed. In less developed countries, with a $\$ 2,500$ GDP per capita, a direct relationship prevails and, excess weight is observed more frequently among the higher social classes (Monteiro, et al. 2004).

Existing studies suggest that the high cost of healthier diets may contribute to the obesity epidemic, especially among the lower-income and low-educated groups (Table 2). At the individual level, obesity rates are linked to low incomes, low levels of education, minority status, and a higher incidence of poverty. Tomer (2011), in his research, indicates that socioeconomic groups with low personal capital, low health capital, and low social capital have higher obesity rates than socioeconomic groups with higher endowments of intangible capital. This is supported by other studies that indicate that higher diet quality, as measured by the Healthy Eating Index, is associated with higher incomes, more education, and with lower rates of obesity and overweight (Henderson, 2007).

According to the overweight/obesity rates presented in Table 2, during 2008-2017 the percentage of obese individuals has been greater for those in higher wealth quintiles. In 2008, the obesity rate for those in the higher quintile was 16.2 percent as compared to 4.0 percent for those in the lower quintile, whereas in 2017 these percentages were 21.3 percent and 16.8 percent, respectively. This data indicates that the obesity rate has increased for both upper- and lower-income quintiles, but it has increased at a much higher pace at the lower quintile. This data is not consistent with Lakdawall's and Philipson's (2002) findings that obesity and poor health status are very much a problem of low-income status. Other studies highlight the role that has been played by such determinants as agricultural modernization, technological innovation in food production, the economic crisis, globalization, and the liberalization of trade (Torres, 2012). With regard to the latter factor, it has been noted that the existence of economies that import products such as high-calorie industrialized foods with a significant sugar and fat content and which are low in unrefined carbohydrates, has produced changes in eating patterns, resulting in an increase in excess weight and obesity in broad sectors of the population. At the same time, observers have warned that income reduction has led many families to adopt new spending strategies which are also, to a great extent, a result of imitating external patterns and of persuasive action exerted by food companies via advertising.

Other factors, including addictive personality, stress, depression, and seeking comfort in familiar foods are among factors leading to higher consumption of sweets and desserts. Also, physical access to supermarkets and grocery stores, marketing and distribution of healthy foods, urban sprawl, and the time spent commuting to work have contributed to the failure to adhere to healthy diets (Morland, et al. 2002). This combination implies that people with weak or negative social capital are more likely to be vulnerable to the influences of the infrastructure of obesity and the economic incentives from the markets regarding food and exercise.

Table 2 shows the main characteristics of obese women in Peru between 2008 and 2017, in which obesity was the main priority of study that measured the rates of obesity and being overweight in the 24 regions in Peru (Family Health and Demographic Survey, 2008 and 2017). In 2017, the natural region with the highest level of obesity at 26.3 percent was the Rest Coast. Based on the educational level, the highest percentage of obese women was among those without education at 29.5 percent and the primary education level at 27.7 percent. Finally, the fourth wealth quintile represents the highest proportion of obese women at 27.5 percent. However, as income quintiles increase, women's obesity levels also tend to rise, except at the highest quintile level. In general, the indicators of obesity are relatively alarming given 
that between 2008 and 2017, the obesity rate has almost doubled, increasing from 14.6 percent in 2008 to 22.9 percent in 2017, which is proof that this topic deserves immediate public policy attention.

TABLE 2

PERCENTAGE OF OBESE WOMEN BETWEEN 15-49 YEARS OLD BY CHARACTERISTICS, 2008 AND 2017 CHARACTERISTICS, 2008 AND 2017

\begin{tabular}{|c|c|c|c|c|c|c|}
\hline \multirow{2}{*}{\begin{tabular}{c|} 
Overweight/Obesity \\
Selected \\
Characteristic
\end{tabular}} & \multicolumn{3}{|c|}{2008} & \multicolumn{3}{|c|}{2017} \\
\hline & $\begin{array}{c}>=25,0 \\
\text { Total } \\
\text { Overweight } / \\
\text { Obesity }\end{array}$ & $\begin{array}{c}25,0-29,9 \\
\text { Only } \\
\text { Overweight }\end{array}$ & $\begin{array}{c}>=30,0 \\
\text { Only } \\
\text { Obesity }\end{array}$ & $\begin{array}{c}=25,0 \\
\text { Total } \\
\text { Overweight/ } \\
\text { Obesity }\end{array}$ & $\begin{array}{c}25,0 \text { - 29,9 } \\
\text { Only } \\
\text { Overweight }\end{array}$ & $\begin{array}{c}>=30,0 \\
\text { Only } \\
\text { Obesity }\end{array}$ \\
\hline \multicolumn{7}{|l|}{ Residence Area } \\
\hline Urban & 52.1 & 35.4 & 16.7 & 61.8 & 37.9 & 24.0 \\
\hline Rural & 40.9 & 31.9 & 9.0 & 56.1 & 37.6 & 18.4 \\
\hline \multicolumn{7}{|l|}{ Natural Region } \\
\hline Lima Metropolitana & 52.5 & 35.7 & 16.7 & 63.0 & 37.7 & 25.2 \\
\hline Rest Coast & 54.0 & 35.3 & 18.7 & 65.1 & 38.8 & 26.3 \\
\hline Mountain Range & 44.5 & 33.5 & 11.0 & 54.9 & 37.5 & 17.4 \\
\hline Jungle & 43.7 & 32.1 & 11.6 & 57.2 & 36.9 & 20.4 \\
\hline \multicolumn{7}{|l|}{ Age } \\
\hline $15-19$ & 20.7 & 18.5 & 2.2 & 28.2 & 22.4 & 5.8 \\
\hline $20-29$ & 40.3 & 31.7 & 8.6 & 49.5 & 34.3 & 15.1 \\
\hline $30-39$ & 60.3 & 41.4 & 18.9 & 71.0 & 41.8 & 29.2 \\
\hline $40-49$ & 68.7 & 42.1 & 26.6 & 80.7 & 46.3 & 34.4 \\
\hline \multicolumn{7}{|l|}{ Level Of Education } \\
\hline Without Education & 49.9 & 39.0 & 10.9 & 68.0 & 38.5 & 29.5 \\
\hline Primary Education & 53.1 & 35.4 & 17.7 & 70.4 & 42.7 & 27.7 \\
\hline Secondary Education & 48.9 & 34.1 & 14.8 & 59.5 & 36.1 & 23.4 \\
\hline Higher Education & 45.8 & 33.7 & 12.1 & 57.6 & 37.8 & 19.9 \\
\hline \multicolumn{7}{|l|}{ Wealth Quintile } \\
\hline Lower Quintile & 32.8 & 28.8 & 4.0 & 53.7 & 36.9 & 16.8 \\
\hline Second Quintile & 41.6 & 32.5 & 9.1 & 63.8 & 40.7 & 23.0 \\
\hline $\begin{array}{l}\text { Intermediate } \\
\text { Quintile }\end{array}$ & 51.2 & 35.1 & 16.1 & 62.2 & 37.7 & 24.4 \\
\hline Fourth Quintile & 55.4 & 37.2 & 18.2 & 63.2 & 35.7 & 27.5 \\
\hline Higher Quintile & 50.5 & 34.5 & 16.2 & 59.3 & 37.9 & 21.3 \\
\hline Total & 49.1 & 34.4 & 14.6 & 60.7 & 37.8 & 22.9 \\
\hline
\end{tabular}

Source: Family Health and Demographic Survey (ENDES), 2008 and 2017.

Social capital (SC) refers to the capacity that is embodied in an individual's social relationships or the bonds and connections between an individual and others. Social capital is embodied in families, institutions, civic communities, and the larger society. The strength and quality of an individual's SC endowment arguably has a relationship to the person's likelihood of becoming obese (Tomer, 2011). 
Tomer (2008) argues that in the presence of strong positive social relationships, people's imbalances are likely to be more muted and less problematic. Conversely, when social capital is weak and negative, people's imbalances are likely to be more pronounced and problematic.

\section{Model to Test Income Inequality, Poverty and Obesity in Peru}

Poverty and obesity vary among regions, as indicated in Table 3 and Table 4, where the Madre de Dios region in Peru has the highest obesity rate of 35.03 percent in 2017 and Huancavelica region has the lowest rate of 12 percent. Table A3 in the appendix shows 2008-2017 data on obesity for all regions in Peru.

TABLE 3

REGIONS WITH HIGHEST OBESITY RATES AMONG WOMEN IN PERU 2017

\begin{tabular}{|l|l|}
\hline Twelve Regions with Women's Highest Obesity Rates & Percent of Obese Women \\
\hline Madre de Dios & 35.03 \\
\hline Tacna & 34.92 \\
\hline Tumbes & 31.76 \\
\hline Moquegua & 31.67 \\
\hline Ica & 30.08 \\
\hline Lima & 25.69 \\
\hline Lambayeque & 25.02 \\
\hline Áncash & 24.87 \\
\hline Ucayali & 23.62 \\
\hline Piura & 23.10 \\
\hline La Libertad & 22.97 \\
\hline Loreto & 21.56 \\
\hline
\end{tabular}

Source: Family Health and Demographic Survey (ENDES), 2017.

TABLE 4

REGIONS WITH LOWEST OBESITY RATES FOR WOMEN IN PERU 2017

\begin{tabular}{|l|l|}
\hline Twelve Regions with Womens Lowest Obesity Rates & Percent of Lowest Obesity Rates \\
\hline Arequipa & 20.71 \\
\hline San Martín & 20.11 \\
\hline Cajamarca & 18.63 \\
\hline Cusco & 17.79 \\
\hline Puno & 17.53 \\
\hline Apurímac & 16.97 \\
\hline Amazonas & 16.90 \\
\hline Ayacucho & 16.78 \\
\hline Huánuco & 15.26 \\
\hline Junín & 15.10 \\
\hline Pasco & 14.95 \\
\hline Huancavelica & 12.00 \\
\hline
\end{tabular}

Source: Family Health and Demographic Survey (ENDES), 2017.

102 Journal of Applied Business and Economics Vol. 21(6) 2019 


\section{The Measurement of Income Inequality and if Inequality Makes You Sick}

Various measures are available to quantify the extent of income inequality within a given community or society. Of these, the Gini coefficient is the one most frequently used. The Gini coefficient varies from 0-1.0 and is defined as half of the arithmetic average of the absolute differences between all pairs of incomes in a population, the total then being normalized on mean income. If income in a population is distributed completely equally, the Gini value is 0 , and if one person has all of the income in a population creating the condition of maximum inequality, the Gini is 1.0.

It is widely acknowledged that individual income is a powerful determinant of individual health (Subramanian \& Kawachi, 2004). Bezruchka (2001) made a claim that income inequality is the foremost cause of our nation's health problems. He dismisses the role individuals can play in safeguarding their own well-being, claiming that "research during the last decade has shown that the health of a group is not affected substantially by individual behaviors such as smoking, diet and exercise." Better prescriptions for a healthy society, he argues, would include a "consumption tax."

Bezruchka is not alone in believing that improving health depends upon transforming economic conditions. Kawachi (2000) in his book "Is Inequality Bad for Our Health?" declares income inequality an "important public health problem." For the past decade public health experts have to expanded their professional agenda beyond health into broader controversies non-medical sources of ill health such as education, class and deprivation. There is no doubt that social conditions, especially poverty, affect physical well-being and length of life. And public health practitioners do have a responsibility to design policies that reliably prevent disease, reduce contagion, and minimize injury. But it is overestimation in thinking they have special expertise in changing the income distribution, in defining social justice, or in producing the instruments that can attain it.

Wilkinson (1996) claims the causal link between income inequality and individual health represents the most important limitation on the quality of life in modern societies. From this he concludes there is "a persuasive case for the redistribution of income." Wilkinson and others point to data purporting to show that health and longevity are, in large part, determined by relative wealth. For example, wealthy countries with more equal income distributions, such as Sweden and Japan, have longer life expectancies than the United States.

Kawachi, et al (1996-2000) expand on Wilkinson's thesis. "The health of a population depends not just on the size of the economic pie, but how the pie is shared." The authors speculate on how social inequality produces differences in health at each step on the socioeconomic ladder. "Income inequality," they observe, "appears to affect health by undermining civil society. Lack of social cohesion leads to lower participation in political activity (such as voting, serving in local government, volunteering for political campaigns)." And they argue that lower participation, in turn, reduces government spending on public goods, such as education, and social safety nets.

Other public health scholars point to the disease-producing anxiety of not being able to keep up with the Joneses. As Lynch \& Kaplan (1997) argue, health may be affected through individual appraisals of relative position in the social order. Even those with good incomes might feel relatively deprived compared to the superrich. There is in fact intriguing evidence that a person's socioeconomic position can affect health. Thus, it is not so much income dispersion itself that matters for health but the proportion of the population that suffers true poverty-related problems, such as under-nourishment, lack of access to timely medical care, and so on. Pollack points out, the health impact of inequality itself is really unknown, once one controls for closely connected characteristics like race. What we are left with is energetic advocacy of a deeply uncertain claim about the connection between health and the degree of income inequality (Satel \& Marmor, 2001).

We got to be cautious in cause and effect relationship between health and wealth that being less welloff produces disease. Indeed, the so-called healthy worker effect suggests that health may determine income. After all, people who are healthier are more likely to hold jobs and to work competitively, that help them advance both their social and economic positions and, in turn, protect their health. We have to be cautious in generalization about the longevity-threatening effect of a socially stratified society as there are some exceptions to the income-inequality schema. For instance, in Denmark, the income inequality 
gap is smaller than in the United States, yet its citizens have a lower average life expectancy than ours. The Japanese have the longest life expectancies, but their social hierarchy is very rigid.

The relationship between obesity and socioeconomic status differs by sex and race and ethnicity group. Among women and specifically non-Hispanic white women, obesity prevalence increases as income decreases, while among non-Hispanic black and Mexican-American men obesity prevalence decreases as income decreases. Although the prevalence of obesity among women with income below 130 percent of the poverty level is higher than among those with higher incomes, most obese women do not have incomes below 130 percent of the poverty level. Among men and women with a college degree, the prevalence of obesity is lower than among those with some college education. Moreover, college educated women are less likely to be obese compared with those with less than a high school diploma. Between 1988-1994 and 2005-2008 the prevalence of obesity increased in adults at all levels of income and education (Ogden, et al. 2010).

\section{MODEL AND METHODOLOGY}

\section{Specification of the Model}

This study follows Subramanian's and Kawachi's (2004) intrinsically multilevel nature of the income inequality hypothesis by contrasting the individual-level and aggregate-level models. Using typical regression notations, the individual-level relation between income and health are specified as follows:

$y_{i}=\beta^{*}\left(x_{i}\right)+e_{i}$,

where $y_{i}$ is the health status of individual $\mathrm{i} ; x_{i}$ is the income of individual $i ; \beta^{*}$ represents the nonlinear, or concave, nature of the relation between $y_{i}$ and $x_{i}$; and $e_{i}$, is the residual differences in individual health, after accounting for individual income. Meanwhile, the aggregate (societal) level relation between income inequality and health are expressed in the following way:

$y_{j}=\alpha\left(W_{j}\right)+u_{j}$

where $y_{j}$ is the average health of a society $j ; W_{j}$ is the income inequality in society $\mathrm{j}$ (measured by Ginicoefficient); $\alpha$ estimates the relation between $y_{j}$ and $W_{j}$; and $u_{j}$ is the residual differences in societal health, after accounting for societal level income inequality. Following the above independent and identical distribution assumptions, one can summarize these societal differences in a variance parameter. Following Subramanian and Kawachi (2004), the following equation is summarized by incorporating the "income inequality hypothesis:"

$y_{j t}=\beta *\left(x_{j t}\right)+\alpha\left(W_{j t}\right)+u_{j}+e_{j t}$

where $y_{j t}$ is the health status of society $j$ at time $t, x_{j t}$ is the income of society $j$ at time $t$ (with $\beta^{*}$ estimating the nonlinear, or concave, nature of the relation between $y_{j t}$ and xjt within a society, and $W_{j}$ is the level of income inequality in society $j$, with $\alpha$ estimating the effect of societal income inequality on individual health: obesity having taken account of the individual income-health relation. An important aspect of the specification in this equation is that variation in health status is seen to be coming from two sources, that is, individual $\left(e_{j t}\right)$ and society $\left(u_{j}\right)$, and the variation attributable to the level of individuals and the level of societies are appropriately partitioned.

Although Subramanian and Kawachi (2004) estimated their model using a multi-level model, in this study, there is an attempt to capture the differences in obesity state that arise from poverty and income inequality. This study also attempts to establish whether there is cointegration among obesity, income inequality, and poverty. The basic idea of this estimation is to check the monotonicity of the relationship, which is crucial for policy purposes. The hypothesis states that both poverty and income inequality 
positively affect obesity. If the relationship is monotonic, then reducing income inequality or poverty will also reduce obesity.

In this study we define $y_{j t}$ as obesity, which is used as a proxy for health status for each state $j$ at time $t ; x_{j t}$ as poverty, which is used as a proxy for poverty status of each state $j$ at time $t ; W_{j t}$ as the level of income inequality in each state $\mathrm{j}$ at time t. The sources and definition of variables are provided in the appendix.

Based on the above information, the following econometric specification for panel data is provided as:

obesity $_{j t}=\alpha_{i}+\beta_{1 j}$ poverty $_{j t}+\beta_{2 j}$ gini $_{j t}+\varepsilon_{j t}$

or, in trans-log form, as:

$l_{\_}$obesity $_{j t}=\alpha_{i}+\beta_{1 j} l_{-}$poverty $_{j t}+\beta_{2 j} l_{-}$gini $_{j t}+\varepsilon_{j t}$

where each variable is expressed in natural logarithmic form and $\mathrm{j}$ (refer to state) $=1,2, \ldots, \mathrm{n} ; t$ (refer to year) $=1,2, \ldots, \mathrm{T}$.

It is important to specify that, for analysis, both the endogenous and explanatory variables of the model (5) are expressed in logarithms, for two main reasons. First, the interpretation of the coefficients is much clearer and more direct in the sense that they represent elasticities, meaning, they indicate in what percentage they respond to obesity in the face of a percentage variation in the poverty rate and income inequality. Second, the variables are expressed on a similar scale, highlighting the linear relationship between them.

Also, according to information available in the Institute of Statistics and Informatics (INEI), corresponding data was used for women in 24 regions of Peru between the ages of 15-49 years. Specifically, the information corresponding to obesity was obtained from the Demographic and Family Health Survey (ENDES), and the information corresponding to poverty and income inequality was obtained from the National Survey of Households on Living Conditions and Poverty (ENAHO).

\section{Methodology}

There are several cointegration tests, such as Engle and Granger (1987), Johansen (1991) and Philips and Ouliaris (1990), which are documented in the time series literature. However, these tests fail to take advantage of information across countries, which lead to a loss of efficiency in estimation. Pedroni (1999) devoted his efforts to develop cointegration tests with panel data. In the present research, the cointegration tests proposed by Pedroni (1999) were chosen to test whether the cointegration relationship exists in the estimated equations.

Before estimating the cointegrating equation, unit root test of the variables were performed according to Levine, et al. (2002), Im, et al. (2003) and Breitung (1999). After the unit root test, the cointegrating equation (5) is estimated to determine whether $l$ obesity, $l$ gini, and $l$ poverty are cointegrated.

\section{RESULT DISCUSSION}

The obesity equation (5) is estimated for a sample of 24 regions in Peru using annual data taken from the Institute of Statistics and Informatics (INEI), specifically that corresponding to the Demographic and Family Health Survey (ENDES) and to the National Survey of Households on Living Conditions and Poverty (ENAHO) in Peru from 2008 to 2017. All variables are in logarithmic form. The first step is to check for the integration properties of the variables involved. The purpose of the unit root test is to verify whether the data series (time series) is non-stationary when running autoregressive modeling. The rationale for testing whether the data is non-stationarity is to be sure that there is no effect from shock that would throw the series out of its long-term equilibrium.

Journal of Applied Business and Economics Vol. 21(6) 2019105 
Table 5 shows the results of the panel unit root tests. For the variables in levels, the specification used for each of the tests was individual intercept and trend, considering the presence of both components in each of the study variables. On the other hand, for the analysis of unitary roots, the specification with intercept was considered given that, when differentiating the series, the trend component is eliminated.

TABLE 5

PANEL UNIT ROOT TEST (LEVEL)

\begin{tabular}{|l|c|c|c|}
\hline \multicolumn{1}{|c|}{ Variable } & LLC & Breitung & IPS \\
\hline 1_obesity & $-13.33 * * *$ & -1.60 & -1.13 \\
\hline 1_poverty & $-6.64 * * *$ & -0.44 & 0.28 \\
\hline 1_gini & $-13.70 * * *$ & $-2.62 * * *$ & $-1.64 * * *$ \\
\hline
\end{tabular}

N.B: LLC=Levin, Lin, Chu (2002), IPS=Im, Pesaran, Shin (2003). The other statistics are described in detail in Breitung (2000). The statistics are asymptotically distributed as standard normal with a left-hand side rejection area. A *** indicates the rejection of the null hypothesis of nonstationarity (LLC, Breitung, IPS) at $1 \%$ level of significance.

\section{TABLE 6
PANEL UNIT ROOT TEST (1st DIFFERENCE) ${ }^{1}$}

\begin{tabular}{|l|c|c|}
\hline \multicolumn{1}{|c|}{ Variable } & LLC & IPS \\
\hline 1_obesity & $-12.07 * * *$ & $-5.75^{* * *}$ \\
\hline 1_poverty & $-7.52 * * *$ & $-2.64 * * *$ \\
\hline 1_gini & $-11.17 * * *$ & $-5.70 * * *$ \\
\hline
\end{tabular}

N.B: LLC=Levin, Lin, Chu (2002), IPS=Im, Pesaran, Shin (2003). The statistics are asymptotically distributed as standard normal with a left-hand side rejection area. A *** indicates the rejection of the null hypothesis of nonstationarity (LLC, Breitung, IPS) at $1 \%$ level of significance.

More or less, a unit root is detected for the level variables, while the first differences appear to be stationary. Table 6 shows the results of the unit root test for the variables in their first-differenced form. As a consequence of the fact that, when differentiating the series, the trend component is eliminated, the unit root tests of the reference table show that the non-stationarity hypothesis is rejected at a highly significant level $(1 \%)$. The panel cointegration tests point to the existence of a long-term relationship between obesity, income inequality, and poverty, as presented in Table 7.

TABLE 7

PANEL COINTEGRATION TEST (PEDRONI, 1999) ${ }^{2}$

\begin{tabular}{|l|c|c|}
\hline \multicolumn{1}{|c|}{ Test } & $\begin{array}{c}\text { Panel } \\
\text { Statistics }\end{array}$ & Group Statistics \\
\hline Variance ratio & 0.7780 & - \\
\hline Rho statistics & 3.0263 & 4.7365 \\
\hline PP statistics & $-7.6893 * * *$ & $-10.5434 * * *$ \\
\hline ADF statistics & $-6.0411 * * *$ & $-6.4490 * * *$ \\
\hline
\end{tabular}

N.B: Statistics are asymptotically distributed as standard normal. The Pedroni statistics are described in detail in Pedroni (1999). The variance ratio test is right-sided, while the other Pedroni tests are left-sided. 
For example, the null of no cointegration is rejected by two of the Pedroni (1999) tests at 1\% level. Specifically, when intercept and trend case is considered, both the panel statistics and group statistics reject the null of no cointegration in two tests. In general, cointegration is understood as the process through which non-stationary variables generate a residual stationary. Thus, it was possible to verify that the variables under study are not stationary in level, but in first difference, therefore, we fulfill the first criterion being the following to verify the degree of integration of the residuals from the estimation of the long-term relationship.

\section{TABLE 8 COINTEGRATING REGRESSION (FMOLS)}

Dependent Variable: L_OBESITY
Method: Panel Fully Modified Least Squares (FMOLS)
Panel method: Pooled estimation
Cointegrating equation deterministics: C
Coefficient covariance computed using default method
Long-run covariance estimates (Bartlett kernel, Newey-West fixed bandwidth)
\begin{tabular}{|l|c|c|c|c|}
\hline \multicolumn{1}{|c|}{ Variable } & Coefficient & Std. Error & t-Statistic & Prob. \\
\hline L_POVERTY & -0.460579 & 0.059765 & -7.706443 & 0.0000 \\
\hline L_GINI & -0.250626 & 0.138767 & -1.806090 & 0.0725 \\
\hline R-squared & 0.825193 & Mean dependent var & 2.869390 \\
\hline Adjusted R-squared & 0.802193 & S.D. dependent var & 0.358183 \\
\hline S.E. of regression & 0.159304 & Sum squared resid & 4.821760 \\
\hline Long-run variance & 0.033031 & & & \\
$* * * * p<0.01, * * p<0.05, ~ * p<0.10$ & & \\
N.B: Panel method is pooled estimation. The Cointegration equation is deterministic.
\end{tabular}
We use Bartlett kernel lag and Newey-West fixed standard error of residuals.

However, the sign associated with both explanatory variables is contrary to expectations. In particular, the sign obtained is negative, this result contrary to what is established by Sobal and Stunkard (1989), Monteiro, et.al., (2004), Tomer (2011) and Henderson (2007).

Although Peru is a developing country, the estimators obtained in the model do not reveal correspondence with what Drewnowski (2012) states: "Diets of lower income households provide cheap, concentrated energy from fat, sugar, cereals, potatoes and meat products - but offer little in the way of whole grains, vegetables and fruit. Low - income consumers are more likely to live in areas with limited access to healthier foods and to be users of fast - food as opposed to full - service restaurants."

On the contrary, the results obtained in this study show that as the socioeconomic status of women has improved, obesity has worsened. This finding presents a serious concern given that higher economic situation does not result in better health conditions, as reported by Sobal and Stunkard (1989). However, the results found in this study were consistent with those reported by Bishwajit (2017) in which women living in households of higher wealth status in Bangladesh and Nepal were found to be significantly more likely to be overweight or obese as compared to those living in poorer households.

These findings are also consistent with the data reported in Table 2 which shows that the wealthiest households in the fourth and higher quintile have higher rates of obesity in women when compared to the lowest quintiles $(21.3 \%$ versus $16.3 \%$ in 2017$)$. Thus, the estimated model of the present investigation is not only consistent with the findings reported by the author of reference, but also with the behavior of the statistical data of Peru. In particular, Graph A1 and Graph A2, make it possible to verify that the data on obesity, poverty, and income inequality which reflect the results obtained in the long-term relationship. Graph A1 allows for verification that high-income regions have higher rates of obesity, while the poorest 
regions have lower rates of obesity. Likewise, Graph A2 reveals that more equal regions have higher rates of obesity, while more unequal regions have lower rates of obesity.

This result also corresponds to the negative and statistically significant correlations presented in Table A2 (Appendix) since poverty, the variable with the highest correlation $(77.48 \%)$ has the highest elasticity with respect to income inequality whose correlation is 53.69 percent. In particular, the obesity-poverty elasticity indicates that for every 1 percent reduction in the poverty rate the obesity rate increases by 0.46 percent, while for the case of the obesity-income inequality elasticity, it is observed that for each 1 percent reduction in the Gini inequality coefficient, the obesity rate increases by 0.25 percent. Thus, the elasticity of obesity-poverty is 1.84 times the elasticity of obesity-inequality of income.

TABLE 9

COINTEGRATING REGRESSION (FMOLS) RESIDUALS (LEVEL) PANEL UNIT ROOT TEST ${ }^{3}$

\begin{tabular}{|l|c|c|c|c|}
\hline \multicolumn{1}{|c|}{ Method } & Statistic & Probability & Cross-sections & Observations \\
\hline Null: Unit root (assumes common unit root process) \\
\hline Levin, Lin \& Chu t* & -9.18164 & $0.0000 * * *$ & 24 & 168 \\
\hline Null: Unit root (assumes individual unit root process) \\
\hline $\begin{array}{l}\text { ADF - Fisher Chi- } \\
\text { square }\end{array}$ & 124.512 & $0.0000 * * *$ & 24 & 168 \\
\hline PP - Fisher Chi-square & 151.948 & $0.0000 * * *$ & 24 & 192 \\
\hline$* * * * \mathrm{p}<0.01, * * \mathrm{p}<0.05,{ }^{*} \mathrm{p}<0.10$
\end{tabular}

In summary, our results suggest that poverty is more responsible for obesity than income inequality, as the elasticity of obesity with respect to poverty is greater than that of income inequality. A final point to note from the long-term model is that the estimated residuals satisfy the condition of stationarity in level. Therefore, the conclusion can be drawn that there is a long-term inverse and stable relationship between obesity, poverty, and inequality.

\section{Causality Test}

Although regression results show a basic type of correlation, it cannot express the causality if one exists. To identify the causality among variables, we conduct the panel Ganger causality test suggested by Hurlin \& Dumitrescu (2012). Table 10 shows the causality test result. It has been determined that there is a unidirectional causal relationship between 1_poverty and 1_obesity at a level of significance of 1 percent. In that sense, poverty is a cause of obesity. Additionally, we find that 1_obesity causes 1_gini unidirectionally at a level of significance of 10 percent.

Obese adults are malnourished, which affects their productivity and income in contrast to those who are not. This finding reduces their income and, in turn, influences the distribution of income. For the case between 1_poverty and 1_gini, the existence of a causal relationship to the Granger is not found. 
TABLE 10

PANEL CAUSALITY TEST

\begin{tabular}{|l|c|c|c|}
\hline Null Hypothesis: & W-Stat. & Zbar-Stat. & Prob. \\
\hline L_POVERTY does not homogeneously cause L_OBESITY & 5.04200 & 5.17342 & $\mathbf{0 . 0 0 0 0 * * *}$ \\
\hline L_OBESITY does not homogeneously cause L_POVERTY & 2.35840 & 1.25377 & 0.2099 \\
\hline L_GINI does not homogeneously cause L_OBESITY & 2.46006 & 1.40226 & 0.1608 \\
\hline L_OBESITY does not homogeneously cause L_GINI & 2.65731 & 1.69037 & $\mathbf{0 . 0 9 1 0 *}$ \\
\hline L_GINI does not homogeneously cause L_POVERTY & 2.06478 & 0.82492 & 0.4094 \\
\hline L_POVERTY does not homogeneously cause L_GINI & 2.10050 & 0.87709 & 0.3804 \\
\hline$* * * * p<0.01, * * p<0.05, * p<0.10$ & &
\end{tabular}

N.B: This test is performed through Dumitrescu and Hurlin (2012).

Thus, once again, the results obtained confirm that for the case of women in Peru between 15-49 years, the reduction of poverty is the main cause of the increase in obesity. In summary, the improvement of the socioeconomic status of Peruvian women has led to a worsening of obesity.

\section{FOOD POLICY INTERVENTIONS}

Without effective intervention, the costs of obesity might well become catastrophic, arising not only from escalating medical expenses but also from diminished worker productivity, caused by physical and psychological disabilities. Future economic losses could mean the difference between solvency and budget imbalances for the Ministry of Health (MINSA), Comprehensive Health Insurance (SIS) and Social Health Insurance (Essalud); between expanding and shrinking health care coverage, and between investment in and neglect of our social infrastructure, with profound implications for our international competitiveness. The human costs would be incalculable (Ludwig, 2007).

Although broad consensus exists regarding the dietary and lifestyle habits needed to prevent and treat childhood obesity, we lack anything resembling a comprehensive strategy for encouraging children to eat a healthful diet and engage in physical activity. Such a strategy would include legislation that regulates junk-food advertising, provides adequate funding for decent lunches and regular physical activities at school restructures in the farm-subsidies program to favor nutrient-dense rather than calorie-dense produce and mandates insurance coverage for preventing and treating pediatric obesity (Ludwig, 2007).

Food policy interventions at the national and international level may be the most promising approach to making healthy food affordable and accessible to all. The World Health Organization (WHO), 2015 stated that the key to maintaining a healthy weight is an affordable supply of fresh nutrient-rich foods. Such access could be facilitated through a combination of agricultural subsidies, pricing policies, regulatory action, and consumer education. This approach would require cooperation between government, academia, and the food industry.

There are two main policy approaches to address obesity. One approach is to reduce the demand for unhealthy products and to change the lifestyle that contributes to obesity. This approach can be achieved by information, education, taxing products, food labeling, and reducing poverty. The second approach is to reduce the supply of unhealthy products by cutting subsidies of agricultural products that keep the costs low and increase consumption of unhealthy products. Ludwig (2007), suggesting there is a need for public policy changes, speaks to the importance of both education and regulation. "It suggests that if we want long-term changes in body weight, we will need to make long-term permanent changes in the environment for children." While education is important, but it is not sufficient, it must be accompanied by restrictions that curb unhealthy habits and with environmental changes that foster healthier ones.

There have been several suggestions to not only remove the offending foods from the consumers' reach but also to discourage consumption and promote alternative healthier diets. These strategies can be 
achieved by imposing taxes on fats and sweets and at schools by limiting access to vending machines containing beverages and snacks and regulating the sales of competitive foods. Agricultural policy options include the provision of economic incentives for the production of healthier foods and removal of existing subsidies.

A basic consequence of economic law is that when something is subsidized, more will be produced while calories from high-fructose corn syrup are unhealthier than those from natural sweeteners, such as sugar. Children spend a significant portion of time in schools, making it natural that the eating habits acquired during school years become life-long.

Menu labeling provides nutritional information regarding calories, carbohydrates, and fat and sodium content. Currently, restaurants that have this information mostly present it on posters or websites, but do not make it readily accessible to consumers when they are making food decisions.

Consumers are mostly ignorant of the food calories, the content of sodium, and sugar or fat in the food they eat. People who eat outside of their homes are more likely to consume supersized portions, and it is estimated that adults who eat outside the home consume 250 more calories per day. Portions served in fast food and restaurant chains have been increasing since the 1970s. Adults often read food labels and make purchasing decisions based on it.

\section{Taxation, Subsidization and Reducing Income Inequality}

A tax placed on a product leads to an increase in its ultimate price. Price increases lead to a reduction in the quantity consumed. This reduction occurs as consumers either cut down or stop purchasing the product. Taxes on items such as alcohol and tobacco in the U.S. have been shown to reduce consumption. One way to reduce the demand for unhealthy food is to impose taxes on items that are most closely associated with obesity. However, taxation alone is unlikely to address the problem; but, it does have several benefits. The revenue gained from taxation can be directed towards consumer education, providing exercise facilities, therefore lowering the public costs of health care. Another option is to impose taxes on restaurant franchises, which will ultimately reduce the supply of restaurants. Similar taxes can be imposed on snack vending machines and restaurants. Poor diet by specific populations can be targeted by taxing products in particular locations.

There have been studies to investigate the potential for soft drink taxes to combat rising levels of child and adolescent obesity through a reduction in consumption. Fletcher, et al (2010) results, based on state soft drink sales and excise tax information between 1989 and 2006 and the National Health Examination and Nutrition Survey, suggest that soft drink taxation, as currently practiced in the United States, leads to a moderate reduction in soft drink consumption by children and adolescents. However, this reduction in soda consumption is completely offset by increases in consumption of other high-calorie drinks. Proponents of soda taxation argue that the practice falls into the realm of a "pigovian tax." Such a tax may increase total economic efficiency in the presence of externalities from consumption. Therefore, taxing such a good not only increases revenue for the government but may also improve overall welfare by reducing "overconsumption" of the good. In the case of the soda tax, reducing consumption may reduce average body weight and obesity rates (McGranahan \& Schanenbach, 2011). This tax, in turn, might reduce health problems related to obesity, such as diabetes and heart disease, and could reduce health care expenditures. It usually does not matter whether a tax is imposed on the producers or consumers of a good, because the producers can pass some of the tax on to the consumers, how much of that tax passes on to the consumers depends on the elasticity of demand and supply for the product.

Research by the University of Illinois's, Powell \& Chaloupka (2012) and his colleagues found that existing state taxes on sugary drinks in the U.S. have not significantly reduced soda consumption or obesity. However, those taxes are relatively small, and a heftier tax would probably have some impact. Still, people have many other sugar sources apart from sodas - which makes a soda tax different from a tobacco or alcohol tax. Thus, the effectiveness of imposing a tax on sugar sources depends on how it affects the price of the products and hence, consumption.

Finally, leveling the playing field by extending subsidies more widely to fruit and vegetable producers could be a positive step toward fighting obesity. As indicated in another segment of this paper, 
income inequality appears to affect health by undermining civil society. With a lack of social cohesion and lower participation in political activity, less government spending on public goods education and social safety nets will take place. Therefore, any policy to reduce income inequality gap can be linked to health and socioeconomic success. Even if the link between inequality and health were clearly established, the public health profession has no particular expertise in designing policies to reduce inequality and solving the problems of social justice.

\section{Access to Healthy Food in Low-Income Areas}

Low-income individuals could have insufficient consumption of healthy foods. There are several reasons for this, such as increased cost of fresh foods in low-income neighborhoods, lack of public transportation to supermarkets, and too few supermarkets and grocery foods in low-income areas that stock healthy foods. The following steps can be taken to increase access to healthy foods, including tax incentives to attract supermarkets to low-income areas, increased access to public transportation, and providing incentives to create more local farmers markets. Although in the present investigation, major obesity is reported in high-income families, it is important to specify that there are also obesity rates in the low-income quintiles. Therefore, ensuring access to healthy foods in low-income areas is vital to reduce obesity levels in Peru. The results of this study also suggest that anti-poverty intervention might have positive effects in terms of reducing food-related health inequalities.

\section{Roles of Advertising and Technology}

Highly processed foods are the focus of many advertisements. According to Diets and Gortmaker (1985) analyzing data for more than 13,000 children; they found that there is a significant association between the amount of time children spent watching television and the prevalence of obesity. They concluded that, among 12 to 17 years old, the prevalence of obesity increased by 2 percent for each additional hour of TV viewing, even after controlling for other variables such as prior obesity, race, and socio-economic status. Also, the hours spent watching television contributed to a sedentary lifestyle and an increased risk of obesity. Young (2015) found that advertising's role in children's food choices and preferences is multi-factorial and complex. Esmaeilpour, et al (2018) examined the impacts of advertising on 330 students in Iran (aged 6-11) participated in the study. The findings revealed that children tended to choose more unhealthy foods after being exposure to unhealthy food advertising. Higher level of entertainment had a greater effect, and was successfully moderated by the activation of health knowledge. They concluded that embedding health messages in advertising help to improve children's health knowledge and therefore, help them to choose less unhealthy food.

The American Psychological Association, Task Force on Advertising and Children (2004), estimated that advertisers spend more than $\$ 12$ billion per year to reach the youth market and that children view more than 40,000 commercials each year. These figures represent dramatic increases over those from the 1970s. Children under the age of two are more likely to accept advertising messages as truthful, accurate, and unbiased (ibid). Food products typically marketed to children include cereals, candies, sweets, sodas, and snack foods. Australia, Canada, Sweden, and Great Britain and Peru have adopted regulations that prohibit advertising in programs watched by young children.

In 2010, WHO endorsed a resolution that urged governments to restrict the promotion and advertising of all energy dense and low-nutritional foods and drinks to children. Since then, all countries have had to deal with the food industry's reluctance to apply such policies that might affect its economic interests. One notable example of this situation took place in Brazil, where a draft regulatory plan, which was only partially approved, banned all advertising messages on foods aimed at children. Brazil now possesses legislation that requires all food advertisements to include warnings for products with high fat, sugar, and salt content. However, the members of the Brazilian Association of Food Industries fail to apply this regulation or apply it only partially. Likewise, agreements have been signed with the food industries of Brazil, Mexico, Chile, and Peru to regulate the content of advertisements for packaged products with low nutritional value. However, it should be stressed that these are voluntary agreements, a situation that has 
been severely criticized by members of academic institutions and non-governmental organizations that promote public health, child protection and consumers' rights (Cardaci, 2013).

Media can also positively influence behavior. As mentioned, options include the reduction or regulation of food advertisements that target children, in addition to the promotion of educational programs that promote healthy eating and exercise, and intervention to reduce the time children spend on media and texting. We should not forget that individual choice cannot be separated from the structural conditions that make it possible. Lifestyles resulting in poor health are not influenced by personal choice; instead, they are a consequence of the economic and social circumstances in which the people are born and live.

\section{Concluding Comments}

The individual may have some aspirations, but these aspirations are likely to be for a complex combination of health, appearance, and weight. Further, the decision-making outcome will be determined, to a great extent, by the relative strength of internal and external factors. If negative external factors (environment) get stronger over time, as they were during the last three decades, without any significant changes in the internal factors, the result would indicate a rising level of obesity as has been observed.

Obesity can be the result of several interactive changes that could be either socio-demographic or economic factors. The government could exploit what causes increases in body weight in order to tackle the promotion of health education, food regulation, and provide counseling in primary care. There is no single strategy that can be effective alone, and rather a combination of different approaches is needed for success. Researchers indicate that it will take a broad set of policies, applied systematically, to effectively reverse the obesity trend (Institute of Medicine Report, May 2012). The faster the government takes action, the lower the impacts of high health care costs on the budget deficit. Simply put, the more the government must spend on health care and the more tax revenues it loses, less will be available for discretionary spending such as education, highways, the environment, defense, and providing safety net services for the nation.

None of this can be accomplished without a policy intervention from the government with support from public interest groups. Stemming the obesity epidemic cannot be separated from stemming the tide of poverty and income inequality gap. The persistence of inequality would seem to reflect a lack of policies aimed at drastically diminishing the gap between different sectors of the population, as well as the predominance of volatility in levels of income and employment. Advocates for equity consider health to be a human right. Likewise, it champions the need to pay attention to the determining factors - at the micro, and macro levels - that are involved in any situation where a successful intervention is being planned (Cardaci, 2013). Despite the growing concern over the increased prevalence of adolescent overweight/obesity in Latin America, little research has been conducted to measure the level of awareness of adolescents regarding the various causes and health consequences of these conditions (McArthur, et al. 2001). We cannot blame individuals and expect personal responsibility to solve the problem. Instead, we need the government to pass a suite of policy changes to encourage healthy diets.

Peru's law is the latest in a series of efforts by Latin American countries to tackle a public health problem that has accompanied the economic boom of the past two decades-more overweight children and an increase in non-communicable diseases such as diabetes and cardiovascular problems. Although several countries have passed laws, implementing regulations have lagged, and some public health experts are calling for international measures - such as those used to tackle cigarette sales - to counter what they say is powerful lobbying by the food and advertising industries (Fraser, 2013). Peru's law immediately drew criticism from legislators, advertisers, and even the Catholic archbishop of Lima, who said that shaping children's dietary habits was a job for parents, not the government. However, the government can play an essential role as the entire country will benefit if the government can deter future health problems by reducing children's consumption of salty, sugary, and high-fat processed foods, according to Luis Fernando Leanes, who headed the Pan American Health Organization (PAHO) office in Peru (cited in Fraser, 2013). 
Moreover, intervention should be more focused on improving the welfare of poorer individuals, in particular, if the reason for obesity is beyond an individual's control that makes them more likely to be obese. Fallon (2015) suggested that regional policy to create healthier communities as a singular national policy to address obesity in Peru would be an ineffective use of resources. Nutrition interventions individually tailored to diverse groups of people are more likely to have an impressionable impact.

In short, there is growing evidence that obesity is largely an economic issue in many countries. Even if the link between inequality, poverty, and health were clearly established and tested, the public health profession has no particular expertise in reducing inequality and solving broader problems of social injustice. This expertise is the responsibility of policymakers to design effective policies to combat income inequality gap and poverty. Multiple community-based strategies are required to combat the increasing prevalence of an overweight and obese population in Peru.

\section{ENDNOTES}

1. For the case of variables in differences, the Breitung test (2000) is omitted because it is based on a specification with individual intercept and trend.

2. For the purpose of the test, the specification with trend and intercept was used since all the series in level present these verified elements via plots of the series as well as a nonzero average test.

3. The unit root tests were performed using the specification without trend and without intercept. This is because, the residuals of the long-term model does not present these components. 


\section{REFERENCES}

Aghion, P., Howitt, P., \& Murtin, F. (2010). The relationship between health and economic growth: When Lucas Meets Nelson-Phelps. Working Paper 15813. Retrieved from http://www.nber.org/papers/w15813, National Bureau of Economic Research.

Andina. (2012, March). Diseases of the heart are the leading cause of death in adults. Retrieved March 20, 2018, from https://andina.pe/agencia/noticia-enfermedades-al-corazon-son-primera-causa-muerteadultos-745153.aspx

Bezruchka, S. (2001, July 16). Does inequality make you sick? The Weekly Standard. Retrieved June 17, 2019, from https://www.aei.org/publication/does-inequality-make-you-sick/

Bishwajit, G. (2017). Household wealth status and overweight and obesity among adult women in Bangladesh and Nepal. Obesity Science \& Practice, 3(2), 185-192.

Braveman, P. (2014). Health disparities and health equality: Concepts and measurement. Annual Review Public Health, 27, 167-94.

Bray, G.A., Nielsen S.J., \& Popkin, B.M. (2004). Consumption of high-fructose corn syrup in beverages May play a role in the epidemic of obesity. The American Journal of Clinical Nutrition, 79(4), 537-543. https://doi.org/10.1093/ajcn/79.4.537

Breitung, J. (1999). The local power of some unit root tests for panel data, (No. 1999, 69). Humboldt University of Berlin, Interdisciplinary Research Project 373: Quantification and Simulation of Economic Processes.

Brownell, K.D., \& Horgen, K.B. (2004). Food fight: the inside story of the food industry. America's obesity crisis, and what we can do about it. Chicago: Contemporary Books.

Cardaci, D. (2013). Child obesity in Latin America: A challenge for health promotion, Global Health Promotion. Sage Journals. Retrieved June 18, 2018, from http://journals.sagepub.com/doi/full/10.1177/1757975913501457

Chou, S.Y., Grossman, M., \& Saffer, H. (2004). An economic analysis of adult obesity: Results from the behavioral risk factor surveillance system. Journal of Health Economics, 23(3), 565-587.

Chou, S.Y., Rashad, I., \& Grossman, M. (2008). Fast-food advertising on television and its influence on childhood obesity. Journal of Law and Economics, 51(4), 599-618.

Dalrymple, T. (2010, May 7). Our big problem. The Wall Street Journal, p. A1.

Dietz, W., \& Gortmaker, S. (1985). Do we fatten our children at the TV set? Obesity and television viewing in children and adolescent. Pediatrics, 75, 807-812.

Dinsa, G.D., Goryakin, Y., Fumagalli, E., \& Suhrcke, M. (2012). Obesity and socioeconomic status in developing countries: A systematic review. Obesity Reviews, 13, 1067-1079. doi: 10.1111/j.1467789X.2012.01017.x

Drewnowski, A., \& Darmon, N. (2005). The economics of obesity: Dietary energy density and energy cost. American Society for Clinical Nutrition, 82(1), 1.

El Comercio. (2014, September 28). Minsa: more than 28\% of Peruvians suffer from heart disease. Retrieved May 25, 2019, from: https://elcomercio.pe/lima/minsa-28-peruanos-sufre-enfermedadcardiaca-368775

Engle, R.F.M., \& Granger, C.W. (1987). Co-integration and error correction: representation, estimation, and testing. Econometrica: Journal of the Econometric.

Esmaeilpour, F., Heidarzadeh, K., Yazdan Mansourian, H., \& Khounsiavash, M. (2018). Children's foodchoice: Advertised food type, health knowledge and entertainment. Journal of Food Products Marketing, 24(4), 476-494, DOI: 10.1080/10454446.2017.1315843

Epub. (2012, June 26). Retrieved June 26, 2018, from https://www.ncbi.nlm.nih.gov/pubmed/22735272

Fallon, S. (2015). Diet, sugary drinks and obesity in Peru. Center for Latin American Studies, University of California Berkeley. Retrieved June 24, 2018, from https://clas.berkeley.edu/research/dietsugary-drinks-and-obesity-peru

Fernald L.C. (2007). Socio-economic status and body mass index in low-income Mexican adults. Soc Sci Med., 64, 2030-2042 [PubMed].

114 Journal of Applied Business and Economics Vol. 21(6) 2019 
Finkelstein, E., \& Zuckerman, L. (2008). The fattening of America: how the economy makes us fat, if it matters, and what to do about it. Hoboken, N.J.: Wiley.

Fletcher, J., Frisvold, D.E., \& Tefft, N. (2010). Can soft drink taxes reduce population weight? Contemporary Economic Policy, 28(January), 23-35.

Fraser, B. (2013). Latin American countries crack down on junk food. The Lancet. Retrieved June 24, 2018, from https://www.thelancet.com/journals/lancet/article/PIIS0140-6736(13)61657-8/fulltext

Frazao, E., \& Allshouse, J. (2003). Strategies for intervention: Commentary and debate. Journal of Nutrition, 133(3). Retrieved January 1, 2011, from http://jn.nutrition.org/content/133/3/844S.short

French, S.A., Story, M., \& Levine, R. (1997). Pricing strategy to promote fruit and vegetable purchase in high school cafeterias. Journal of the American Dietetic Association, 97(9), 1008-1010.

French, S.A., Story, M., \& Jeffrey, R.W. (2001). Environmental influences on eating and physical activity. Annual Review of Public Health, 22, 309-335.

Heggeness, M.L., \& Hokayem, C. (2013). Life on the edge: Living near poverty in the United States, 1966-2011. U.S. Census Bureau SEHSD Working Paper 2013-02, Washington, DC.

Henderson, L.J. (2007). Obesity, poverty and diversity: Theoretical and strategic challenges. Obesity, business, and public policy, (pp. 57-75). Cheltenham, UK: Edward Elgar.

Hojjat, T.A., \& Hojjat, R. (2017). The Economics of Obesity: Poverty, Income Inequality and Health. SpringerBrief in Public Health. Retrieved from http://www.springer.com/series/10138

Hou X., Jia W., \& Bao Y., et.al., (2008). Risk factors for overweight and obesity, and changes in body mass index of Chinese adults in Shanghai. BMC Public Health, 8, 389, [PubMed].

Howitt, P. (2005). Health, Human capital, and economic growth: A Schumpeterian perspective in health and economic growth: Findings and policy implications, edited by G. López-Casasnovas, B. Rivera and L. Currais. Cambridge, MA: MIT Press, 19-40.

Huayanay-Espinoza, C.A., Quispe, R., Poterico, J.A, Carrillo-Larco, R.M., Bazo-Alvarez, J.C., \& Miranda, J.J. (2017). Parity and overweight/obesity in Peruvian women. Prev Chronic Dis., 14, 160282. DOI: http://dx.doi.org/10.5888/pcd14.160282

Hurlin, C., \& Dumitrescu, E. (2012). Testing for granger non-causality in heterogeneous Panels. HAL Id: halshs-00224434 https://halshs.archives-ouvertes.fr/halshs-00224434v2.

Im, K.S., Pesaran, M.H., \& Shin, Y. (2003). Testing for unit roots in heterogeneous panels. Journal of Econometrics, 115(1), 53-74.

INEI. (2008). Encuesta Nacional de Hogares, 2004-2008. In: Instituto Nacional De Estadística E Informática. INEI: Lima.

Institute of Medicine Report. (2012, May). Accelerating progress in obesity prevention solving the weight of the nation. Retrieved May 20, 2019, from

http://nationalacademies.org/hmd/ /media/Files/Report\%20Files/2012/APOP/APOP_rb.pdf

Jenkins, H.W. (2013, January 29). Coke and the calories wars. The Wall Street Journal, p. A11.

Jiménez, M.M., Mantilla, E., Huayanay-Espinoza, C.A., Gil, K., García, H., \& Miranda, J.J. (2015). Demand for training and availability of health science professionals in Peru. Rev Peru Med Exp Salud Public, 32(1), 41-50.

Johansen, S. (1991). Estimation and hypothesis testing of cointegration vectors in Gaussian vector autoregressive models. Econometrica: Journal of the Econometric Society, 1551-1580.

Kawachi, I. (2000). Is Inequality Bad for Our Health. Boston: Beacon Press.

Kawachi, I.B., Kennedy, B., \& Wielinson, R. (1999-2000). The Society and Population Health Reader: Income Inequality and Health. New York: New Press.

Khan, M.M., \& Kraemer, A. (2009). Factors associated with being underweight, overweight and obese among ever-married non-pregnant urban women in Bangladesh. Singapore Med J., 50, 804-813 [PubMed].

La República. (2012, September 30). Obesity causes $22.77 \%$ of deaths from cardiovascular diseases. Retrieved May 20, 2019, from: https://larepublica.pe/salud/663539-la-obesidad-causa-el-2277-demuertes-por-enfermedades-cardiovasculares 
Lakdawalla, D., \& Philipson, T. (2002). The growth of obesity and technological Change: A theoretical and empirical examination. Working Paper (8946). National Bureau of Economic Research. Retrieved January 1, 2011, from http://www.nber.org/papers/w8946

Lakdawalla, D., \& Philipson, T. (2009). The growth of obesity and technological change. Economics \& Human Biology, 7(3), 283-293.

Levin, A., Lin, C.F., \& Chu, C.S.J. (2002). Unit root tests in panel data: asymptotic and finite-sample properties. Journal of Econometrics, 108(1), 1-24.

Loret de Mola, C., Quispe, R., Valle, G.A., \& Poterico, J.A. (2014). Nutritional transition in children under five years and women of reproductive age: A 15-years trend analysis in Peru. PLoS ONE, 9(3), e92550. doi:10.1371/journal.pone.0092550.

Lucas, C., Charlton, K.E., \& Yeatman, H. (2014). Nutrition advice during pregnancy: do women receive it and can health professionals provide it? Maternal Child Health Journal, 18(10), 2465-78. CrossRef (http://dx.doi.org/10.1007/s10995-014-1485-0), PubMed. Retrieved from http://www.ncbi.nlm.nih.gov/pubmed/24748213

Ludwig, D.S. (2007). Childhood obesity: The shape of things to come. New England Journal of Medicine, 357(23), 2325-2327. Retrieved October 28, 2012, from http://dx.doi.org/10.1056/NEJMp0706538

Lynch, J.W., \& Kaplan, G.A. (1997). Understanding how inequality in the distribution of income affects health. Journal of Health Psychology, London. Thousand Oaks and New Delh: Sage Publications.

Martorell, R., Khan, L.K., Hughes, M.L., \& Grummer-Strawn, L.M. (1998). Obesity in Latin American women and children. Journal of Nutrition, 128, $1464-1473$.

McArthur, L., Peña, M., \& Holbert, D. (2001). Effects of socioeconomic status on the obesity knowledge of adolescents from six Latin American. International Journal of Obesity, 25, 1262-1268. Nature Publishing Group.

McCrory, M.A., Fuss, P.J., Hays, N.P., Vinken, A.G., Greenberg, A.S., \& Roberts, S.B. (1999). Overeating in America: association between restaurant food consumption and body fatness in healthy adult men and women ages 19 to 80. US National Library of Medicine - National Institute of Health, 7(6), 564-571.

McGranahan, L., \& Schanzenbach, D.W. (2011). Who would be affected by soda taxes? Chicago Fed Letter, Federal Reserve Bank of Chicago, 284, 2-4.

Mispireta, M., Rosas, A., Velazquez, J., Lescano, A., \& Lanata, C. (2007). Transición nutricional en Perú, 1991-2005. Rev Peru Med Exp Salud Pública, 24, 129-135.

Monteiro, C.A., Conde W.L., \& Popkin, B.M. (2001). Independent effects of income and education on the Risk of obesity in the Brazilian adult population. J Nutr, 131, 881S-886S.

Monteiro, C.A., Moura, E.C., Conde, W.L., \& Popkin, B.M. (2004). Socioeconomic status and obesity in adult populations of developing countries: a review. Bulletin of the World Health Organization, 82(12), 940-946.

National Institute of Statistics and Information Technology -INEI. (2000). Methodology for Measuring the Poverty in Peru. Retrieved May 23, 2019, from https:/www.inei.gob.pe/media/MenuRecursivo/metodologias/pobreza01.pdf

National Institute of Statistics and Information Technology -INEI, (2017, May 30). 17.6\% of the population aged 15 and over have high blood pressure. Retrieved from https://www1.inei.gob.pe/prensa/noticias/el-176-de-la-poblacion-de-15-y-mas-anos-de-edadtienen-hipertension-arterial-9771/

National Institute of Statistics and Information Technology -INEI. (2018). Evolution of monetary poverty 2007-2017, P. 165. Retrieved May 20, 2019, from https://www.inei.gob.pe/media/cifras_de_pobreza/informe_tecnico_pobreza_monetaria_20072017.pdf

Neel, J.V. (1962). Diabetes mellitus: a "thrifty" genotype rendered detrimental by "progress"? American Journal of Human Genetics, 14, 353-362.

116 Journal of Applied Business and Economics Vol. 21(6) 2019 
Ogden, C., Lamb, M., Carroll, M.D., \& Flegal, K.M. (2010). Obesity and socioeconomic status in adults: United States, 2005-2008. Retrieved May 31, 2014, from http://www.cdc.gov/nchs/data/databriefs/db50.pdf

Organización Panamericana de la Salud, Recomendaciones de la Consulta de Expertos de la Organización Panamericana de la Salud obre la promoción y publicidad de alimentos y bebidas no alcohólicas dirigida a los niños en la Región de las Américas. Washington, D.C.: OPS; 2011. Google Scholar

Overweight, obesity, and health risk. National Task Force on the Prevention and Treatment of Obesity. (2000). Arch Intern Med., 160(7), 898-904.

Phillips, P.C., \& Ouliaris, S. (1990). Asymptotic properties of residual based tests for cointegration. Econometrica: Journal of the Econometric Society, 165-193.

Peru Reports. (2015) Retrieved from https://perureports.com/2015/06/16/perus-middle-class-downslightly-over-four-years/

Peru Reports. (2018, May 20). Retrieved from https://perureports.com/poverty-inequality/

Peru Reports. (n.d.). Retrieved from https://perureports.com/poverty-inequality/

Peru 21. (2017, March 7). Diseases to the heart: Report reveals everything that Peru spends and how they can be avoided. Retrieved May 30, from https://peru21.pe/lima/enfermedades-corazon-informerevela-gasta-peru-evitar-68227

Pipoli, R. (2018). UN Report: Obesity growing uncontrollably in Latin America. Retrieved April 30, 2018, from https:/www.upi.com/Top_News/World-News/2018/11/07/UN-report-Obesitygrowing-uncontrollably-in-Latin-America/4431541619290/

Popkin, B.M. (2001). The nutrition transition and obesity in the developing world. J Nutr, 131, 871S$873 \mathrm{~S}$.

Poskitt, E.M. (2014). Childhood obesity in low- and middle-in-come countries. Paediatr Int Child Health, 34(4), 239- 49.

Poterico, J.A., Bernabé-Ortiz, A., Loret de Mola, C., \& Miranda, J.J. (2012. Association between television viewing and obesity in Peruvian women. Rev Saude Publica, 46(4), 610-6.

Poterico. J.A., Stanojevic, S., Ruiz-Grosso, P., Bernabe-Ortiz, A., \& Miranda, J.J. (2012). The association between socioeconomic status and obesity in Peruvian women. Obesity (Silver Spring), 20(11), 2283-9. Cross Ref (http://dx.doi.org/10.1038/oby.2011.288) PubMed. Retrieved from http://www.ncbi.nlm.nih.gov/pubmed/21959344

Powell, L.M., \& Chaloupka, F.J. (2009). Food prices and obesity: evidence and policy implications for taxes and subsidies. The Milbank Quarterly, 87(1), 229-257.

Prentice, A.M. (2006). The emerging epidemic of obesity in developing countries. Int J Epidemiol, 35, 93-99.

Rolls, B.J., Morris, E.L., \& Roe, L.S. (2002). Portion size of food affects energy intake in normal-weight and overweight men and women. American Journal of Clinical Nutrition, 76(6), 1207-1213.

Salmasi, L., \& Celidoni, M. (2017). Investigating the poverty-obesity paradox in Europe. Economics and Health Biology accepted manuscript. http://dx.doi.org/10.1016/j.ehb.2017.02.005

Satel, S., \& Marmor, T.R. (2001). Does inequality make you sick? The Weekly Standard.

Sobal, J., \& Stunkard, A.J. (1989). Socioeconomic status and obesity: A review of the literature. Psychological Bulletin, 105(2), 260-275.

Subramanian, S.V., \& Kawachi, I. (2004). Income Inequality and health: What have we learned so far? Epidemiologic Reviews, 26(1), 78-91.

Subramanian, S.V., \& Smith, G.D. (2006). Patterns, distribution, and determinants of under- and overnutrition: a population-based study of women in India. Am J Clin Nutr, 84, 633-640.

Stutzer, A. (2007). Limited self-control, obesity and the loss of happiness. Social Science Research Network, Discussion Paper No. 2925, 10. Retrieved January 1, 2011, from http://papers.ssrn.com/sol3/papers.cfm?abstract id=1001413

The World Bank, Peru. (2019). World development indicators. Retrieved from https://databank.bancomundial.org/data/source/world-development-indicators\# 
The World Bank, UNICEF, WHO. (2012). Child Malnutrition Estimates. New York: UNICEF; Geneva: WHO; Washington, DC: The World Bank.

The World Health Organization. (2015). Global health observatory indicator views. Geneva (CH). Retrieved May 5, 2016, from http://apps.who.int/gho/data/node.imr.

The World Health Organization. (2015). Web. Retrieved February 10, 2016.

The World Health Organization. (2018). Obesity and overweight. Retrieved April 30, 2018, from https://www.who.int/news-room/fact-sheets/detail/obesity-and-overweight

Tomer, J. (2011). What causes obesity? And why has it grown so much? Challenge, 54(4), 22.

Tomer, J.F. (2008). Intangible capital: its contribution to economic growth, well-being and rationality. Cheltenham, UK: Edward Elgar.

Torres, F. (2012.). Transformaciones de la demanda alimentaria como factor de la obesidad en México, en: Rivera, J., Hernández, M., Aguilar, C. \& Vadillo, C. (Ed) Obesidad en México.

Recomendaciones para una política de Estado. México: UNAM; 2012, pp.125-144. Google Scholar.

Troiano, R.P., \& Flegal, K.M. (1998). Overweight children and adolescents: description, epidemiology, and demographics. Pediatrics, 101, 497 - 504.

Uauy, R., Albala, C., \& Kain, J. (2001). Obesity trends in Latin America: transiting from under- to overweight. Journal of Nutrition, 131, 893S-899S.

United Nation Report. (2018). Obesity growing uncontrollably in Latin America. Retrieved June 2019, from https://www.upi.com/Top_News/World-News/2018/11/07/UN-report-Obesity-growinguncontrollably-in-Latin-America/4431541619290/

Wilkinson, R. (1996). Unhealthy Societies: The Afflictions of Inequality. London, New York: Routledge.

Wilcox, B., Kunkel, D., Cantor, J., Dowrick, P., Linn, S., \& Palmer, E. (2004). Report of the APA Task Force on Advertising and Children. American Psychological Association.

Winterman, D. (2012, September 25). Child obesity: Why do parents let their kids get fat? BBC news magazine. Retrieved June 10, 2013, from http://www.bbc.co.uk/news/magazine-19661085

Young, B. (2003). Does food advertising influence children's food choices? A critical review of some of the recent literature. International Journal of Advertising, 22(4), 441-459. DOI: 10.1080/02650487.2003.11072862.

Zizza, C., Siega-Riz, A.M., \& Popkin, B.M. (2001). Significant increase in young adults' snacking between 1977-1978 and 1994-1996 represents a cause for concern! Preventive Medicine, 32(4), 303-310. 


\section{APPENDIX}

\section{TABLE A1 \\ DESCRIPTION OF THE VARIABLES}

\begin{tabular}{|c|c|c|c|}
\hline Variable & Unit & Description & Source \\
\hline obesity & $\begin{array}{l}\text { In Body Mass } \\
\text { Index (BMI). The } \\
\text { natural logarithm } \\
\text { of BMI index, } \\
\text { which is more } \\
\text { than } 30 \text {, is used } \\
\text { as the variable } \\
\text { "obesity". In } \\
\text { econometric } \\
\text { specification, we } \\
\text { denote it as } \\
\text { l_obesity. }\end{array}$ & $\begin{array}{l}\text { The body mass index (BMI), or Quetelet index, is a value } \\
\text { derived from the mass (weight) and height of an individual. The } \\
\text { BMI is defined as the body mass divided by the square of the } \\
\text { body height and is universally expressed in units of } \mathrm{kg} / \mathrm{m}^{2} \text {, } \\
\text { resulting from weight in kilograms and height in metres. If } \\
\text { pounds and inches are used, a conversion factor of } 703 \\
\left(\mathrm{~kg} / \mathrm{m}^{2}\right) /\left(\mathrm{lb} / \mathrm{in}^{2}\right) \text { must be applied. When the term BMI is used } \\
\text { informally, the units are usually omitted. Commonly accepted } \\
\text { BMI ranges are underweight: under } 18.5 \text {, normal weight: } 18.5 \\
\text { to } 25 \text {, overweight: } 25 \text { to } 30 \text {, obese: over } 30 \text {. } \\
\text { The data structure is in panel and the data is collected from } \\
2008 \text { to } 2017 \text { for all regions in Peru. }\end{array}$ & $\begin{array}{l}\text { Demographic } \\
\text { and Family } \\
\text { Health Survey } \\
\text { (ENDES - } \\
\text { INEI) } \\
\text { https://proyecto } \\
\text { s.inei.gob.pe/e } \\
\text { ndes/ }\end{array}$ \\
\hline poverty & $\begin{array}{l}\text { In percentage. } \\
\text { The variable is } \\
\text { measured as the } \\
\text { natural logarithm } \\
\text { of the percentage. } \\
\text { In econometric } \\
\text { specification, we } \\
\text { denote it as } \\
\text { l_poverty }\end{array}$ & $\begin{array}{l}\text { Poverty is measured as the number of persons below in poverty } \\
\text { line and is expressed as percentage. } \\
\text { In Peru, the official poverty definition supported by the } \\
\text { National Institute of Statistics and Informatics (INEI, 2000) } \\
\text { uses the poverty line method is used for consumption, the value } \\
\text { of all the goods and services consumed by the household is } \\
\text { incorporated, regardless of the form of acquisition or } \\
\text { attainment. The use of consumer spending has the advantage } \\
\text { that is the best indicator to measure well-being, because it } \\
\text { refers to what a household consumes and not what it can } \\
\text { potentially consume when measured by income. Another } \\
\text { favorable aspect is that consumption is one more variable stable } \\
\text { income, which allows a better measurement of the poverty level } \\
\text { trend. } \\
\text { In the estimates of consumption expenditure made by the } \\
\text { National Institute of Statistics and Informatics (INEI), all } \\
\text { sources of expenditure are considered, monetary expenditure, } \\
\text { as well as the various forms of acquisition of goods and } \\
\text { services that do not imply a monetary payment of part. This last } \\
\text { group includes self-consumption and self-supply, as well as in- } \\
\text { kind payments that come from households' own economic } \\
\text { activities and also the elements of expenditure received by } \\
\text { transfers from other households or by part of public and private } \\
\text { organizations. Likewise, within the components of expenditure, } \\
\text { expenses in health and public education are excluded, due to } \\
\text { the lack of adequate prices to value said services consumed by } \\
\text { households. Finally, the imputation for the consumption of } \\
\text { river water or ditch is also excluded, because the degree of } \\
\text { transformation of said goods is almost nil and there is no } \\
\text { commercial value that allows an adequate valuation. } \\
\text { The data structure is in panel and the data is collected from } \\
\text { 2008 to } 2017 \text { for all regions in Peru. }\end{array}$ & $\begin{array}{l}\text { National } \\
\text { Household } \\
\text { Survey on } \\
\text { Living } \\
\text { Conditions and } \\
\text { Poverty } \\
\text { (ENAHO- } \\
\text { INEI) } \\
\text { http://iinei.inei. } \\
\text { gob.pe/microda } \\
\text { tos/ }\end{array}$ \\
\hline
\end{tabular}




\begin{tabular}{|c|c|c|c|}
\hline gini & $\begin{array}{l}\text { In ratios. The } \\
\text { variable is } \\
\text { measured as the } \\
\text { natural logarithm } \\
\text { of the percentage. } \\
\text { Gini coefficient is } \\
\text { used to measure } \\
\text { the extent of } \\
\text { inequality. In } \\
\text { econometric } \\
\text { specification, we } \\
\text { denote it as } \\
\text { lgini. }\end{array}$ & $\begin{array}{l}\text { The Gini coefficient is a measure of inequality of variance. It is } \\
\text { often applied to measure inequality of incomes in a particular } \\
\text { area. A score of "0" on the Gini coefficient represents complete } \\
\text { equality, i.e., every person has the same income. A score of } 1 \\
\text { would represent complete inequality, i.e., where one person has } \\
\text { all the income and others have none. The information was } \\
\text { tabulated from the National Household Survey on Living } \\
\text { Conditions and Poverty (ENAHO-INEI) conducted by the } \\
\text { National Institute of Statistics and Informatics (INEI). We refer } \\
\text { gini coefficient as income gini coefficient and the ratio } \\
\text { measures the extent of income inequality. } \\
\text { The data structure is in panel and the data is collected from } \\
2008 \text { to } 2017 \text { for all regions in Peru. }\end{array}$ & $\begin{array}{l}\text { National } \\
\text { Household } \\
\text { Survey on } \\
\text { Living } \\
\text { Conditions and } \\
\text { Poverty } \\
\text { (ENAHO- } \\
\text { INEI) } \\
\text { http://iinei.inei. } \\
\text { gob.pe/microd } \\
\text { atos/ }\end{array}$ \\
\hline
\end{tabular}

TABLE A2

CORRELATION OF THE VARIABLES

\begin{tabular}{|l|c|c|c|}
\hline $\begin{array}{c}\text { Correlation / } \\
\text { Probability }\end{array}$ & L_OBESITY & L_POVERTY & L_GINI \\
\hline L_OBESITY & 1.000000 & & \\
\hline & ----- & & \\
\hline L_POVERTY & -0.774750 & 1.000000 & \\
\hline \multicolumn{2}{|c|}{0.0000} & ---- & \\
\hline L_GINI & -0.536908 & 0.589959 & 1.000000 \\
\hline \multicolumn{2}{|c|}{0.0000} & 0.0000 & ---- \\
\hline
\end{tabular}


TABLE A3

PERCENTAGE OF WOMEN 15-49 YEARS OLD WITH OBESITY (IMC $>=30,0$ ) IN THE DIFFERENT REGIONS IN PERU

\begin{tabular}{|c|c|c|c|c|c|c|c|c|c|c|}
\hline Regions & 2008 & 2009 & 2010 & 2011 & 2012 & 2013 & 2014 & 2015 & 2016 & 2017 \\
\hline Amazonas & 8.90 & 11.90 & 8.83 & 8.70 & 12.53 & 14.36 & 15.81 & 16.02 & 17.65 & 16.90 \\
\hline Áncash & .90 & 16.40 & 15.19 & 13.80 & 16.70 & 22.50 & 21.71 & 18.45 & 24.07 & 24.87 \\
\hline Apurímac & .90 & 11.00 & 9.44 & 8.50 & 11.69 & 15.37 & 14.34 & 13.95 & 15.44 & 16.97 \\
\hline Arequipa & 5.00 & 16.50 & 17.09 & 20.20 & 23.42 & 23.24 & 24.02 & 20.98 & 20.25 & 20.71 \\
\hline Ayacucho & 3.30 & 7.40 & 9.20 & 12.30 & 11.27 & 13.74 & 14.83 & 15.20 & 17.15 & 16.78 \\
\hline Cajamarca & .00 & 10.50 & 9.83 & 13.00 & 11.25 & 14.00 & 13.35 & 11.90 & 13.99 & 18.63 \\
\hline Cusco & 11.40 & 10.10 & 8.89 & 12.80 & 10.67 & 12.02 & 15.62 & 17.08 & 16.24 & 17.79 \\
\hline Hua & 6.10 & 6.80 & 6.19 & 7.10 & 10.27 & 9.60 & 10.56 & 12.14 & 11.39 & 12.00 \\
\hline Huánuco & 9.50 & 9.80 & 11.56 & 13.50 & 12.91 & 13.76 & 15.46 & 17.37 & 17.90 & 15.26 \\
\hline Ica & .40 & 25.10 & 24.27 & 25.30 & 25.72 & 25.19 & 27.72 & 27.41 & 31.33 & 30.08 \\
\hline Junín & 11.90 & 9.80 & 11.63 & 12.80 & 13.44 & 14.31 & 16.49 & 14.52 & 14.84 & 15.10 \\
\hline La Lib & 16.40 & 17.20 & 17.79 & 19.60 & 20.07 & 24.28 & 22.93 & 20.58 & 25.10 & 22.97 \\
\hline Lam & 14.70 & 14.70 & 14.62 & 16.70 & 14.19 & 22.54 & 17.11 & 22.22 & 23.86 & 25.02 \\
\hline Lima & 17.30 & 19.40 & 18.93 & 19.10 & 20.59 & 21.94 & 24.21 & 25.07 & 23.89 & 25.69 \\
\hline Loreto & 11.10 & 10.30 & 12.67 & 12.90 & 11.49 & 18.30 & 20.12 & 17.83 & 18.76 & 21.56 \\
\hline Madre de Di & 20.60 & 23.00 & 26.71 & 23.80 & 30.28 & 31.88 & 27.26 & 27.96 & 32.80 & 35.03 \\
\hline Moquegua & 21.50 & 22.10 & 25.66 & 23.90 & 28.72 & 29.59 & 30.15 & 31.24 & 30.20 & 31.67 \\
\hline Pasco & 10.20 & 14.00 & 15.24 & 13.30 & 14.28 & 14.70 & 15.01 & 16.76 & 15.43 & 14.95 \\
\hline Piura & 14.50 & 15.30 & 19.03 & 20.90 & 19.57 & 21.75 & 21.20 & 24.64 & 23.55 & 23.10 \\
\hline Puno & 11.10 & 12.90 & 12.92 & 14.50 & 18.07 & 19.33 & 18.32 & 19.16 & 22.28 & 17.53 \\
\hline San $M$ & 8.20 & 12.70 & 12.23 & 11.80 & 16.86 & 15.92 & 17.27 & 18.55 & 16.58 & 20.11 \\
\hline Tacna & 24.70 & 25.60 & 28.58 & 31.00 & 29.40 & 28.36 & 31.76 & 30.45 & 33.14 & 34.92 \\
\hline Tumbe & 21.00 & 22.60 & 19.54 & 22.90 & 21.87 & 25.72 & 25.49 & 28.53 & 29.88 & 31.76 \\
\hline Ucayali & 14.70 & 13.10 & 14.39 & 16.30 & 19.87 & 22.72 & 23.67 & 21.03 & 22.59 & 23.62 \\
\hline Peru & 14.60 & 15.70 & 15.80 & 17.00 & 17.93 & 20.22 & 20.90 & 20.92 & 21.20 & 22.91 \\
\hline
\end{tabular}




\section{FIGURE A1}

\section{THE RELATIONSHIP BETWEEN OBESITY AND POVERTY IN THE DIFFERENT REGIONS IN PERU}
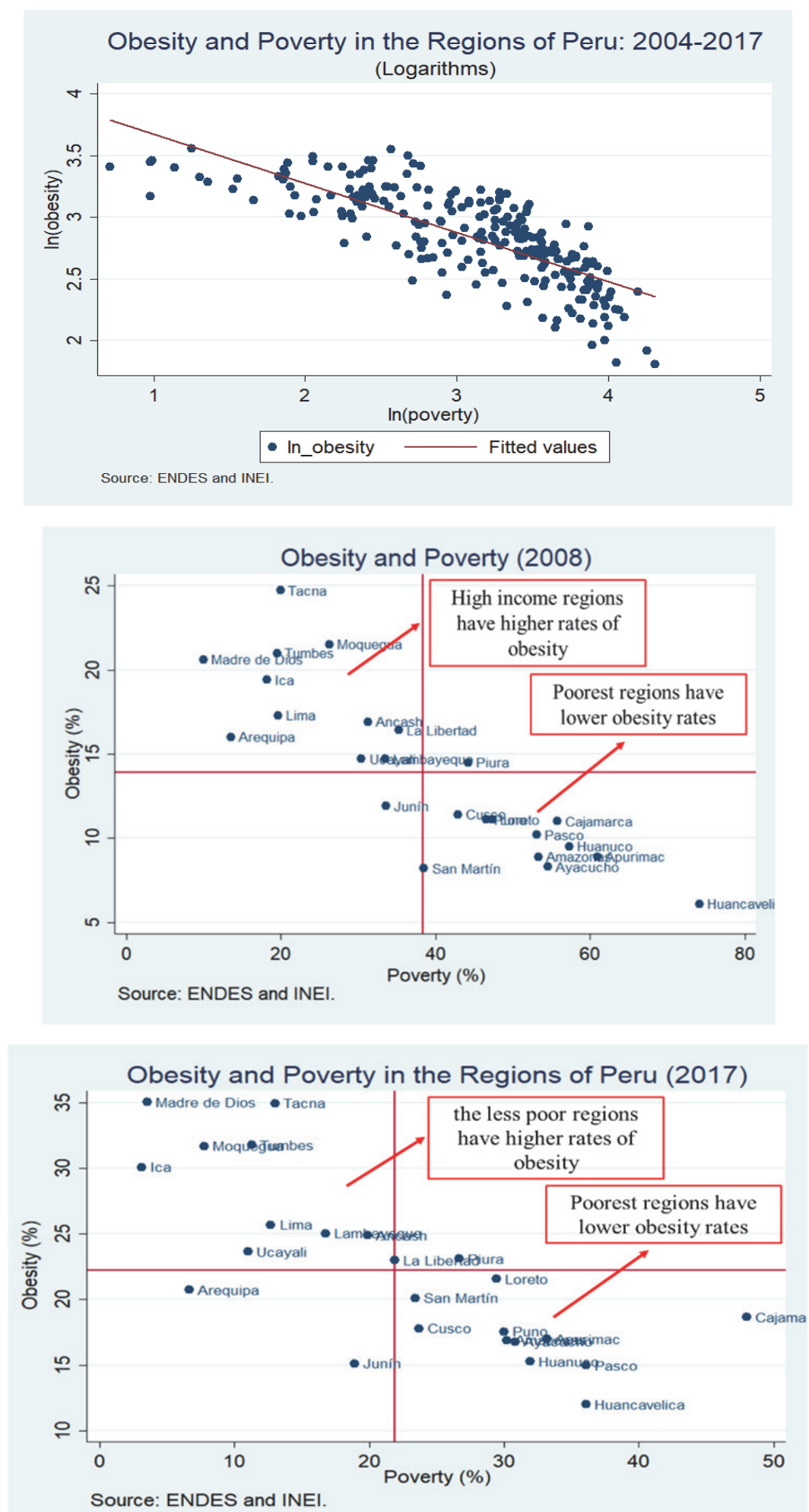

Source: Family Health and Demographic Survey (ENDES), 2008-2007 


\section{FIGURE A2}

\section{THE RELATIONSHIP BETWEEN OBESITY AND INCOME INEQUALITY IN THE DIFFERENT REGIONS IN PERU}
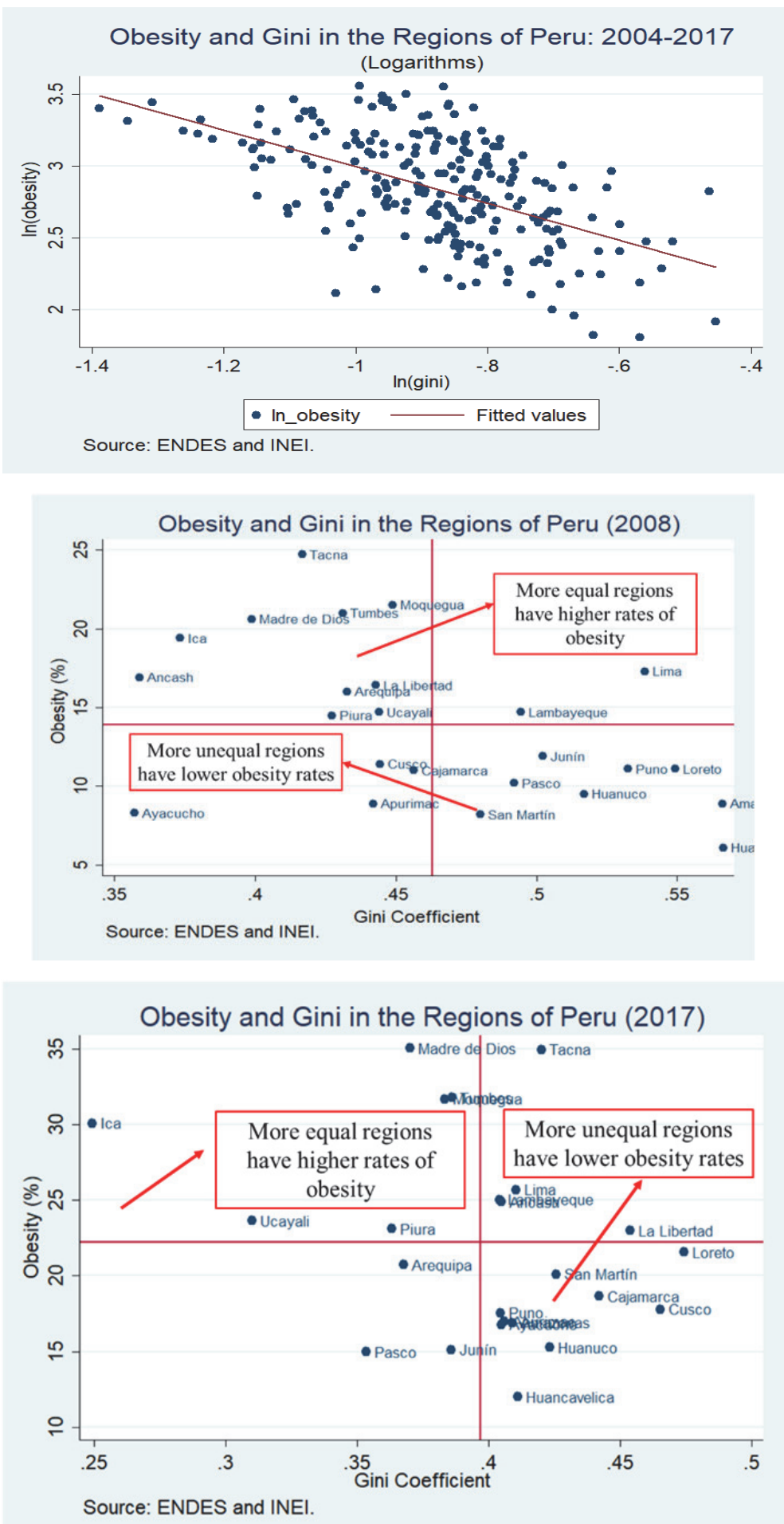

Source: Family Health and Demographic Survey (ENDES), 2008-2017. 